\title{
Land Use Change Effects on Carbon and Nitrogen Stocks in the Pyrenees during the Last 150 Years: a Modelling Approach
}

\author{
Yueh-Hsin Lo ${ }^{1}$, Juan A. Blanco ${ }^{1,}{ }^{*}$, Rosa M. Canals ${ }^{1}$, Ester González de Andrés ${ }^{1}$, Leticia San \\ Emeterio $^{1}$, J. Bosco Imbert ${ }^{1}$, Federico J. Castillo ${ }^{1}$
}

1 Dep. Ciencias del Medio Natural, Universidad Pública de Navarra, Campus de Arrosadía, Pamplona, Spain 31006.

E-mail adresses: yuehhsin.lo@unavarra.es; rmcanals@unavarra.es; ester.gonzalez@unavarra.es; leticia.sanemeterio@unavarra.es; bosco.imbert@unavarra.es; federico.castillo@unavarra.es

* Author to whom correspondence should be addressed; E-Mail: juan.blanco@ unavarra.es Tel.: +34-948-169-859; Fax: +34-948-168-930

\begin{abstract}
In the southern Pyrenees, human population and therefore land uses have changed from forests to pastures, then crops, and back to pastures and secondary forests during the last two centuries. To understand what such rapid land use changes have meant for carbon (C) and nitrogen (N) stocks, we used data from two forest sites in the western Pyrenees, combined with regional data on pastures and crop production (potato, cereal), to calibrate the ecosystem-level model FORECAST. Then, we simulated 150-year of land use for each site, emulating historical changes. Our estimates show that the conversion from forests into pastures and crops created $\mathrm{C}$ and $\mathrm{N}$ deficits (378-427 $\mathrm{Mg} \mathrm{C}^{-1}$, 4.0-4.6 $\mathrm{Mg} \mathrm{N} \mathrm{ha}^{-1}$ ) from which these sites are still recovering. The main ecological process behind the creation of these deficits was the loss of the ecological legacy of soil organic matter (SOM) created by the forest, particularly during conversion to farming. Pastures were able to reverse, stop or at least slow down the loss of such legacy. In conclusion, our work shows the deep impact of historical land use in ecosystem attributes, both in magnitude of removed $\mathrm{C}$ and $\mathrm{N}$ stocks and in duration of such impact. Also, the usefulness of ecological modelling in absence of historical data to estimate such changes is showcased, providing a framework for potential $\mathrm{C}$ and $\mathrm{N}$ stocks to be reached by climate change mitigation measures such as forest restoration.
\end{abstract}

Keywords: Pyrenees, C pools, $\mathrm{N}$ available, ecological modelling, FORECAST model, land use change. 


\section{Introduction}

Nowadays it is becoming apparent that we are at the onset of a new geological era named the Anthropocene, due to human-induced changes in biodiversity, topography, hydrological and geochemical cycles, and even climate (Zalasiewicz et al. 2008). All these changes together constitute the so-called global change, which is already having important consequences on different ecological patterns and processes (Vitousek 1994, Steffen et al. 2011).

Opening new lands for farming has been identified as one of the factors generating net $\mathrm{C}$ releases to the atmosphere, especially when forests or bogs are converted into arable land due to the large amounts of $\mathrm{C}$ contained in their soils. On the other hand, when farming ceases and the land reverts to forest or other uses (through natural succession or as part of ecological restoration plans) the land could become a net sink of atmospheric C (Dixon et al. 1994). Land use history is therefore tightly linked to human-related release or fixation of atmospheric $\mathrm{C}$.

Land-use change has a long history around the world in any region where human population practiced natural resource management tasks other than hunting and gathering. In particular, the Mediterranean region has more than 10,000 years of landscape changes since the establishment of arable farming. Since then, farming has become the most widespread form of land use in Europe (Stoatte et al. 2001).

In the Pyrenees, the historical events caused alternating periods of expansion and contraction of pastures, croplands, and forests (see Supplementary Material). However, despite the importance of land-use change in dominating long-term net terrestrial fluxes of $\mathrm{C}$, estimates of the annual flux are uncertain relative to other terms in the $\mathrm{C}$ budget (Prentice et al. 2001). Knowing such rates of $\mathrm{C}$ fluxes would be useful to identify the most likely and promising strategies for climate change mitigation through land-use actions, such as forest and grassland management. The direct estimation of historical influences of human activities in forest through Europe is considered as an extremely difficult task, due to the long history and overlapping effects of human activities. However, one indirect method that can be applied is scenario modelling (Herold et al. 2011).

Clearing and farming of forest lands have clear implications in many ecosystem attributes, and especially on soils. These effects include, but are not limited to: 1) substantial nutrient removals in harvested timber, influencing the balance of remaining plant-available nutrients in the long term (Blanco et al. 2005); 2) Physical effects of ploughing, which changes soil structure, influencing soil oxygenation, water retention, and water flow, which in turn affects mineralization rates of soil organic matter (SOM) (Ballard 2000); 3) Canopy removal during thinning or harvesting, affecting soil temperature and moisture regimes (Blanco 2004); 4) Prescribed fire or slash burning, resulting in substantial nutrient pulses (Canals et al. 2014), which may be used by the new vegetation or may be lost from the system through volatilization (notably of $\mathrm{N}$ and $\mathrm{S}$ ) and, in some cases, fly-ash losses (Kimmins et al. 1997); and 5) Changes in nutrient content and availability by fertilization, which is some cases could result in soil acidification from nitrification (Ballard 2000). All these effects have a direct translation into reducing soil fertility in the long-term, affecting ecosystem productivity and C storage capacity (Morris et al. 1997, Wei and Blanco 2014).

C stocks in the Pyrenees Mountains have gone through important fluctuations in the latest decades (ÁlvaroFuentes et al. 2011), but there is little quantitative information on the changes that have occurred in longer 
time spans, specifically in the latest century and a half. Therefore, our ultimate goals were: 1) to estimate the potential deficit in $\mathrm{C}$ and $\mathrm{N}$ pools caused by historical land-use change; 2) to identify which type of land use (crop, pasture or forest) has been mainly responsible for such deficit; and 3) to identify which ecological processes could have been more implicated in generating this deficit. Knowing such information could provide a better framework for $\mathrm{C}$ sequestration and storage management plans focused on climate change mitigation, including reforestation, afforestation, improved grassland management or low-impact farming. To provide an initial estimation of the magnitudes of such changes, we have used the ecosystem-level model FORECAST. The model is specially designed to examine the impacts of different management strategies or natural disturbance regimes on long-term site productivity and $\mathrm{C}$ sequestration. A detailed description of the FORECAST model can be found in (Kimmins et al. 1999, 2010) and a brief description of the algorithms simulating $\mathrm{C}$ sequestration and $\mathrm{N}$ limitation will be presented in the next section. This model has been tested in boreal, temperate, subtropical and tropical forests (Bi et al. 2007, Blanco et al. 2007, Blanco and González 2010, Seely et al. 2010, Wang et al. 2013, Wei and Blanco 2014), including the Pyrenees (Castrillón et al. 2013), as well as in agroforestry (Welham et al. 2007, 2010) and restoration applications (Welham et al. 2012).

\section{Materials and Methods}

Supplementary materials provide the extended data on the research sites and calibration parameters. Here we provide a description of the most important data sources.

\subsection{Research sites}

Given the variety of environments existing in the Pyrenees, we have calibrated the model FORECAST to simulate forests, crops and grasslands in two sites of the western Pyrenees region that could be considered as archetypical sites: a "low elevation" site (elevation below 1,000 m.a.s.1, close to the human population centers), and a "high elevation" site (elevation above 1,000 m.a.s.l., far from the human population centers). Therefore, we used data from two contrasting experimental forest sites that have been monitored since 1999, representing the two extremes of a site quality gradient throughout the western Pyrenees, in the province of Navarre (northern Spain). The lower elevation site represents highly productive $P$. sylvestris forests in Navarre, with higher soil $\mathrm{N}$ than in the other site (Table 1). The higher elevation site is an example of a low production $P$. sylvestris forest in Spain. Tree densities are similar at both sites, but tree size is significantly higher in Aspurz. Both sites are pine-dominated stands, with a minor presence of broadleaves (less than 10\% of the total stand density) of broadleaves. Pteridium aquilinum (L.) Kuhn and Rubus spp. are the two dominant species in the understory at both sites. Soil at the low elevation site is Haplic Alisol, and Dystric Cambisol at the low elevation site (Table 2). Supplementary Material provides a location map (Figure S1) and ombrothermic diagrams (Figure S2).

\subsection{The FORECAST model}

FORECAST is a management-oriented, deterministic, non-spatial, stand-level forest growth and ecosystem dynamics simulator that operates at annual time steps. The model simulates the dynamics of all forest carbon stocks required under the Kyoto Protocol (aboveground biomass, belowground biomass, litter, dead wood and soil organic carbon). It complies with the carbon estimation methods outlined by the IPCC (Penman et al. 2003). The model uses a hybrid approach to vegetation growth modelling, as it merges the use of empirical 
data (i.e. growth and yield tables and field data, among others, see section 2.3) modified by the simulation of the most important ecological processes (Kimmins et al. 1999, Landsberg 2003). This hybrid approach assumes that the best predictor of vegetation growth for a site with a given combination of climate and nutrient limitation is the observed vegetation growth itself. In other words, vegetation productivity for a given site depends on the combination of climatic, topographic and edaphic features of that site. Therefore, observed vegetation productivity is a variable that implicitly has already taken climate effects into account. This approach, combined with the annual time step, reduces the need of meteorological or climate data, which are not used as input variables in FORECAST, but assumes that climate for the simulated scenario is similar to the climate during the time when empirical data were recorded. A detailed discussion of this approach and the full model have been described in before (Kimmins et al. 1999, 2010, Penman et al. 2003) and therefore only a summary of the main driving function to calculate vegetation growth is provided here.

The model uses a mass balance approach to estimate how nutrients circulate in the ecosystem, and how their availability limits vegetation growth (trees, plants and bryophytes) together with available light in the canopy (Figure 1). Detailed descriptions of decomposition, tree uptake and biogeochemical cycles can be found in (Kimmins et al. 1999, Kimmins 1993). FORECAST has three application stages: 1) assembling calibration data and generating historical rates of key ecosystem processes; 2) model initialization by establishing the ecosystem condition for the beginning of a simulation run; and 3) simulation of tree and plant growth.

\subsubsection{Generation of historical rates of ecological processes}

Projection of stand growth and ecosystem dynamics is based upon a system of equations that links the rates of key ecological processes regulating the availability of, and competition for, light and nutrient resources with vegetation growth. The rates of these processes are calculated from a combination of historical bioassay data (biomass accumulation in component pools, stand density, etc., see (Kimmins et al. 1999) for a detailed description of input parameters needed) and measures of certain ecosystem variables (e.g. decomposition rates, photosynthetic saturation curves, etc.) by relating biologically active components (foliage and small roots) with calculations of nutrient uptake, capture of light, and net primary production. With the calibration data obtained from different sources (see section 2.2), the model calculates the annual rates of different ecological processes (tree growth, litterfall production, mortality, etc.) that should had happened to produce the observed data on tree growth and density provided by the user. Therefore, for each plant species for which historical data are provided, the total net primary production (TNPP) that occurred for each annual time step (t) is calculated with Equation (1).

$$
\mathrm{TNPP}_{\mathrm{t}}=\Delta \text { biomass }_{\mathrm{t}}+\text { litterfall }_{\mathrm{t}}+\text { mortality }_{\mathrm{t}}
$$

where $\Delta$ biomass $_{\mathrm{t}}=$ the sum of the change in mass of all the biomass components of the particular species in time step $t$; litterfall $\mathrm{l}_{\mathrm{t}}=$ the sum of the mass of all ephemeral tissues that are lost in time step $t$ (e.g., leaf, branch, bark and reproductive litterfall, and root death); and mortality $\mathrm{t}_{\mathrm{t}}=$ the mass of plants that die in time step $t$. Change in biomass ( $\Delta$ biomass $_{\mathrm{t}}$ ) in each time step is derived from a series of age-biomass curves created with empirical data (see a detailed description of the process in [Kimmins et al. 1999]). Litterfall is calculated using user-defined values based on empirical litterfall rates. For trees, mortality is derived from a series of 
age-stand density curves created with empirical data (for detailed descriptions on litterfall and mortality simulations in FORECAST, see (Kimmins 1993, Kimmins et al. 1999). For trees, mortality is calibrated through two different parameters: curves of historical stand density for different ages and the proportion of mortality that is due to non-interspecific competition factors. Together, both parameters allow simulating the endemic, low level mortality events caused by pests and diseases typical of coniferous forests. For plants (grasses and crops in these simulations) mortality is not simulated explicitly as no individual plants are simulated, but it is assumed to be included in the curves of biomass per area and age.

The model also estimates the Shade-Corrected Foliage N content (SCFN), which represents the amount of $\mathrm{N}$ in fully illuminated foliage that was required to produce the calculated historical TNPP, based on the empirical data. To estimate foliage shading, FORECAST simulates canopy foliage biomass as a "blanket" that covers the stand and that is divided in several layers of $0.25 \mathrm{~m}$ height, each of them increasingly darker from the top to the bottom of the canopy. Tree, understory, grasses or crop canopies are therefore simulated in the same way. The light absorbed by each layer is calculated based on the foliage biomass present in each time step and a user-defined empirical curve of foliage mass-proportion of full light (light absorption by foliage). Once an estimation of self-shading has been completed for a particular time step using the method described above, FORECAST calculates the equivalent $\mathrm{N}$ content after correcting for self-shading (SCFN, Equations 2 and 3).

$$
\begin{gathered}
S C F N_{t}=\sum_{i=1}^{n}\left(F N_{t, i} \times P L S C_{i}\right) \\
\mathrm{FN}_{\mathrm{t}, \mathrm{i}}=\text { foliage biomass } \mathrm{t}_{\mathrm{t}, \mathrm{i}} \mathrm{x} \text { foliar } \mathrm{N} \text { concentration }
\end{gathered}
$$

Where $\mathrm{FN}_{\mathrm{t}, \mathrm{i}}=$ mass of foliage $\mathrm{N}$ in the ith quarter-meter height increment in the live canopy at time $t$, $\mathrm{PLSC}_{\mathrm{i}}=$ photosynthetic light saturation curve value for the associated light level in the ith quarter-meter height increment in the live canopy, $\mathrm{n}=$ number of quarter-meter height increments in the live canopy at time $t$. The mean photosynthetic rate of the foliage in canopy level $i$ is calculated by combining simulated light intensities in canopy level $i$ with input data that define photosynthetic light saturation curves for the foliage type in question. Finally, the driving function curve for potential growth of a given species in FORECAST is the Shade-Corrected Foliar N Efficiency (SCFNE) calculated for each annual time step ( $\mathrm{t}$ ) with Equation 4:

$$
\mathrm{SCFNE}_{\mathrm{t}}=\mathrm{TNPP}_{\mathrm{t}} / \mathrm{SCFN}_{\mathrm{t}}
$$

When data describing the growth of a species on more than one site quality (defined as the combination of nutrient availability and climate conditions for a specific site, see [Kimmins 1993, Kimmins et al. 1999]) are provided, SCNFE function curves will be generated during the calibration stage for each site quality. To calculate the nutritional aspects of tree and plant growth, FORECAST requires data on nutrient concentration in each different tree organ. Nutrient dynamics in this study were restricted to $\mathrm{N}$, the most limiting nutrient at these sites (Blanco 2004).

Net primary production in FORECAST is allocated among the different organs in the same ratios as the input data on biomass accumulation curves for each organ. If data are given for sites that differ in productivity, the model will simulate changing resource allocation strategies as the simulated nutritional site quality varies during a run of the model. Thus, empirically-observed variations in production allocation strategies on sites of 
different nutritional quality are used to guide the simulation of changing production allocation in response to simulated changes in nutritional site quality during the simulations.

Kimmins et al. (Kimmins et al. 2008) have shown how the combination of light and nutrient limitation is not enough to explain complex ecological patterns in simulated models, and they recommended including also understory vegetation. Therefore, a comparable but simpler (e.g. no data on bark, wood, mortality, etc.) set of data for understory vegetation must be provided to represent this ecosystem component. Lastly, data describing decomposition rates for various litter and humus types are required to simulate nutrient cycling. Decomposition rates are defined by the user (using values from empirical studies) and are affected by site quality, which in turn is defined depending on nutrient and water availability (Kimmins 1993, Kimmins et al. 1999). Litter is composed by a collection of different litter cohorts, each with its age and decomposition stage. Snags and logs are tracked by placing them into different categories depending on their original sizes (with slower decomposition rates for snags and for stems with larger sizes).

\subsubsection{Model initialization}

To establish initial site conditions we carried-out a modified version of the typical spin-up process used to let the model reach a stable state (Hashimoto et al. 2011, Shi et al. 2013). Initial conditions were created by running the model for eight or twelve 150-year cycles (for the high and low elevation sites, respectively) ending with a stand-replacing wildfire that killed all the trees in the stand and allowed for a new cohort of trees to grow (Blanco et al. 2007, Blanco and González 2010). These runs allowed the model to accumulate SOM until reaching a stable value (97.2 and $364.6 \mathrm{Mg} \mathrm{C} \mathrm{ha}^{-1}$ for the high and low elevations sites, respectively). The final products of these runs were used as the starting conditions for the natural baseline scenarios (see section 2.2).

\subsubsection{Simulation of tree and plant growth}

During the simulation stage, for each annual time step, the annual potential growth (APG) of vegetation is driven by the photosynthetic production of the foliage biomass (Equation 5). The productive capacity of a given quantity of foliage biomass (photosynthetic rate) is assumed to be dependent on foliage $\mathrm{N}$ content corrected for shading created by the canopy of the simulated site $\left(\mathrm{SCFN}_{\mathrm{t}}{ }^{*}\right)$. $\mathrm{SCFN}_{\mathrm{t}}$ * is different from the $\mathrm{SCFN}_{\mathrm{t}}$ that was previously calculated during the internal calibration stage (section 2.2.1). During the simulation stage the canopy simulated corresponds to the site defined by the user for that particular scenario, which can be different from the empirical canopy data used during the calibration stage, and therefore $\mathrm{SCFN}_{\mathrm{t}}{ }^{*}$ is particular for each simulation.

$$
\mathrm{APG}_{(\mathrm{t}+1)}=\mathrm{SCFN}_{\mathrm{t}}^{*} \times \mathrm{SCFNE}_{\mathrm{t}}
$$

Where: $\mathrm{APG}_{(\mathrm{t}+1)}=$ annual potential growth for a given species in the next time step. During the simulation stage, the model interpolates between the different curves of SCFNE calculated before to find the site quality of the simulated site.

Nutrient uptake requirements to support APG are calculated based on rates of biomass growth and data on nutrient concentration in the different biomass components. Nutrient availability is calculated based on empirical data describing litter and humus decomposition rates, changes in chemistry as decomposition 
proceeds, and the size of nutrient pools in the mineral soil and humus (cation exchange capacity (CEC) and anion exchange capacity (AEC), respectively). If the availability of nutrients for each time step is less than required to support APG, vegetation growth is limited by nutrients and the realized annual growth is lower than APG.

Simulating of $\mathrm{C}$ and $\mathrm{N}$ in soil is achieved by assuming that SOM can be divided into two different pools: litter and humus. When the decomposition process of each litter has ended (as defined by reaching a percentage of the initial mass), this material becomes part of the active humus. This pool represents resistant plant material derived from structural litter and soil-stabilized microbial products. Typical turnover rates for this pool range from 20 to 100 years, depending of the conditions simulated. The last SOM pool is the passive humus, which accumulates the remaining decomposed materials and represents material very resistant to decomposition and includes physically and chemically stabilized SOM, with typical turnover times between 200 to 2000 years. $\mathrm{N}$ content in these pools is defined by the $\mathrm{N}$ concentration in the senesced plant material and in the humus. Similar approaches to SOM simulation have been used in models such as CENTURY (Parton et al. 1987), ROMUL (Chertov et al. 2001), or ICBM (André and Kättere et al. 2001) models.

$\mathrm{N}$ cycling in FORECAST is based on a mass balance approach (Figure 2) where $\mathrm{N}$ can exist in three distinct pools: 1) the plant biomass pool; 2) the available soil nutrient pool, and 3) the SOM/forest floor pool. Inputs and outputs of $\mathrm{N}$ to the ecosystem are simulated in a four-stage process for each annual time step. The "available N" pool in FORECAST can be assimilated to represent the interchangeable N present in the soil during one year as $\mathrm{NH}_{4}{ }^{+}, \mathrm{NO}_{3}{ }^{-}$or labile organic $\mathrm{N}$ fractions with turnover rates shorter than one year. $\mathrm{N}$ deposition and $\mathrm{N}$ fixed by bryophytes and other microorganisms are simulated as constant annual $\mathrm{N}$ fluxes that directly reach the soil solution and are incorporated into the available $\mathrm{N}$ pool. Available $\mathrm{N}$ pool is calculated by simulating consecutively the different inputs and outputs of the biogeochemical cycle: deposition, fertilization, seepage, leaching, mineralization, immobilization (Figure 2). Being an annual model, nutrients released from sources with average decomposition times from days to months (mineral or organic fertilizers, or manure) are lumped together in the same fluxes. A detailed description of the simulation of each of these fluxes in FORECAST can be found in Kimmins et al. (1999) and (Blanco et al. 2012). The definition of site fertility based on $\mathrm{N}$ availability assumes that soil moisture is not limiting in these sites (Figure S2). However, soil moisture is still implicitly affecting the simulation by the use of the parameter "maximum leaf biomass" which is directly correlated with soil moisture availability (Kimmins et al. 1999).

$\mathrm{C}$ and $\mathrm{N}$ cycles are linked through the use of the foliar $\mathrm{N}$ efficiency as the driving function of the model (amount of biomass generated in a year per kg of foliar N, Agren and Bossata 1996). Therefore, a limitation in $\mathrm{N}$ uptake will result in a reduction of foliar $\mathrm{N}$, reducing biomass produced by the trees. Nutrient uptake demands on sites of different $\mathrm{N}$ fertility are based on observed biomass accumulation rates and tissue nutrient concentrations on these sites, allowing for internal cycling of nutrients.

\subsection{Calibration data}

Values of the main parameters used to simulate Scots pine are provided in Table 3. Data on historical tree growth patterns (age-biomass curves) were gathered from published growth and yield tables (García and Tella 1983, Puertas 2003). Data on tree light and N requirements were derived from literature (Oliver and Larson 
1996, Terradas 2001). Litter production was derived from field data (Kimmins 2004, Blanco et al. 2006a). Decomposition rates and soil data were derived from field data (Blanco et al. 2011, Fernández 2013, Martínez 2013) and literature (Blanco et al. 2006b). Atmospheric deposition rates are based on data from (Spanish Ministry of Environment 2003), and mineral weathering rates are from literature (Kimmins et al. 2004, Fisher and Binkley 2000). Understory growth patterns (limited in the simulation to Rubus spp. and Pteridium aquilinum L.) nutrient concentration and litterfall decomposition rates were derived from literature (Mitchell et al. 2000, Imbert et al. 2008, García del Barrio 2000). Values of soil-related parameters can be found in the Supplementary Material (Table S1).

Calibration values for crops and grasses are provided in Table 4. For potato (Solanum tuberosum L.), data on crop growth and related nutrient cycling were obtained from literature (Kolbe and Stepahn-Beckmann et al. 1997a, b). For barley (Hordeum vulgare L.), local grain production data (Pérez et al. 2007, Goñi and Segura 2012, Torrecilla 2012) were combined with published grain-shoot-ratios to obtain plant biomass (Arraya et al. 2010, Dordas 2012, Gómez Mercado et al. 2009, Marley et al. 2013). Apostolides et al. (Marley et al. 2013) have estimated that average barley yield in England duplicated from $18^{\text {th }}$ to late $19^{\text {th }}$ century, and it has duplicated again since then. This fact, combined with local expert knowledge and assuming similar temporal changes in barley yield potential in the Pyrenees, indicated the need to reduced current grain productions by $50 \%$ to discount almost a century of improvement in crop varieties, mechanization, fertilization and pest control, as well as plantation in sub-optimal sites. Nutrient demands were also obtained from literature sources (Dordas 2012, Duke 1983). Data on pastures came from field observations by the authors (Canals et al. 2014, Canals and San Emeterio, unpub. data). Pastures were composed by multispecific, semi-natural permanent grasslands, dominated by grasses (such as Festuca rubra L., Agrostis capillaris L. and Cynosurus cristatus L.) which coexisted with legumes (Trifolium repens L., Lotus corniculatus Lam.) and other forbs (Sebastià et al. 2006).

\subsection{Land use change scenarios}

To estimate the effects of historical land use changes on $\mathrm{C}$ and $\mathrm{N}$ pools, we compared two different scenarios for each site.

1) Baseline scenario. The baseline scenario for each site assumed that forests remained forests (with its present species composition, see Table 1) and were unmanaged for the whole duration of the simulations (150 years). In the western Pyrenees, natural fire return intervals are estimated in 150-160 years (Rius et al. 2009). Therefore, one event of such natural disturbance was included in each 150year run by simulating a stand-replacing wildfire at year 75 . This time was arbitrarily chosen as the middle point of the simulation, in the lack of more detailed data on fire occurrence in relationship to stand features. Wildfires in FORECAST are simulated as a fraction of stand live biomass that is killed (100\% biomass dead in stand-replacing events). Then, a fraction of this dead biomass becomes litter and the rest disappears in combustion. For a detailed description of these processes see (Kimmins 1993, Kimmins et al. 1999). Baseline scenarios are therefore hypothetical benchmarks for comparing against the historical land-use scenarios, and do not pretend to represent the condition of pristine Pyrenean forests during the $19^{\text {th }}$ and $20^{\text {th }}$ centuries. 
2) Historical scenario. One scenario trying to emulate the average land use changes in the former 150years was created for each site, based on the descriptions of human history and land use changes in the western Pyrenees (Chocarro et al. 1990, García-Ruiz and Lasanta-Martínez 1990). Such scenarios are representative of the changes that have taken place in most of the Pyrenees, but they do not pretend to simulate the history of any specific location. For the most fertile, low elevation forest, we simulated a clear-cut followed by slash burning in the 1850 s, followed by 25 years of pasture tending, then 25 years of cereal growth (with the traditional two-field system of crop tending one year, followed by a year of fallow), then 25 years of potato growth (same fallow system), then 25 years of pasture, active land management ending by the late 1950s, and allowing 50 years of forest regrowth until beginning of the $21^{\text {st }}$ century. For the less fertile, high elevation forest, the land use change pattern started with clear-cut and slash burning in the 1850 s, followed by 50 years of pasture use, then 25 years cereal at the beginning of the $20^{\text {th }}$ century, 25 years pasture, finally being the land abandoned by the $1950 \mathrm{~s}$. The end of active land management allowed 50 years or forest regrowth until present times.

The variable taken into account to compare $\mathrm{C}$ and $\mathrm{N}$ pools between the historical and baseline scenarios was the accumulated net biomass production (adding up aboveground biomass growth of foliage, branches, stems, and bark; and belowground biomass growth of rhizomes, coarse and fine roots). Over time, mortality and litterfall transfer this biomass growth into coarse woody debris, litter and SOM. C and N deficits at the beginning of the $21^{\text {st }}$ century are defined as the difference in total nutrient content between an ecosystem that has undergone the historical land use changes and an ideal non-managed ecosystem occupying the same site.

\section{Results}

Vegetation $\mathrm{C}$ and total $\mathrm{C}$ in the baseline scenario were quite similar to field data from the high elevation sites, whereas for the low elevation site, field estimates were in between the historical and the baseline scenarios (Figure 3). Such results are quite sensible because the high elevation site has never (as long as locals can remember) used for farming and maybe only temporarily for pastures. Such history of minimum human intervention has probably affected little the forest, keeping it close to the hypothetical baseline scenario. However, the actual history of land use at the low elevation site is different, and probably closer to the historical scenario. Being a relatively flat site, close to a river bank and to the village of Aspurz, it was likely used as cropland or pasture for most of the late- $19^{\text {th }}$ and early- $20^{\text {th }}$ century. However, forest management actions taken during the second half of the $20^{\text {th }}$ century have probably helped trees to grow faster than if left alone (matching the vegetation $\mathrm{C}$ estimated for the baseline scenario), but there has not been time for soil $\mathrm{C}$ to recover, and therefore it still remains close to the historical scenario estimations.

Model estimations for cereal total biomass were about $3 \mathrm{Mg} \mathrm{ha}^{-1}$, and grain yields $0.8 \mathrm{Mg} \mathrm{ha}^{-1}$. Estimated potato biomass (dry weight) was on average $17.3 \mathrm{Mg} \mathrm{ha}^{-1}$. For pasture production, the estimated maximum biomass at both sites was around $4.5 \mathrm{Mg} \mathrm{ha}^{-1}$. Pastures temporally increased litter and therefore slowed down SOM losses compared to crops (Table 6).

For the low elevation site, forest stands growing after timber harvesting in the historical scenarios had similar patterns of $\mathrm{C}$ storage to the baseline scenario. However, at this site $\mathrm{C}$ and $\mathrm{N}$ pools were still lower than the baseline scenario at the end of the simulation (Table 5). For the historical scenarios at both sites, a large 
part of $\mathrm{N}$ was probably lost when the initial forest was removed and the land cleared, by exporting the harvested products or through the site preparation management (Figure 4). Later, as SOM decomposed, the associated $\mathrm{N}$ was lost by leaching of other processes. The large $\mathrm{N}$ pool stored in recalcitrant SOM coming from the forest was therefore consumed over time. However, there was not a direct translation on smaller soil $\mathrm{N}$ pool into less available $\mathrm{N}$. Specifically, pastures were able to keep a stable level of $\mathrm{N}$ available whereas crops caused a drop in $\mathrm{N}$ availability levels (Figure 4).

\section{Discussion}

\subsection{Simulated long-term dynamics}

For the research sites, the historical data on vegetation growth described by Blanco et al. (2006b) are the only available, and no long-term data series of pristine forests could be found. Therefore, direct detailed validation of model predictions versus field data was not possible, and model uncertainty could not be quantified. However, previous partial model evaluation for the research sites indicated acceptable model performance for litterfall fluxes (Castrillón et al. 2013). In addition, recent detailed sensitivity analysis to changes in parameters defining soil and underground variables indicated that model projections are robust to uncertainty in calibration values ecosystems (Gárate and Blanco 2013).

Comparing model estimations with other forest sites, aboveground biomass estimates reached values in the same range than other reports for the central Pyrenees (Puigfábregas and Alvera 1977: $225 \mathrm{Mg} \mathrm{ha}^{-1}$ for stand age 65 years), and eastern Pyrenees (Pausas and Fons 1992: 142-253 Mg ha ${ }^{-1}$ for stand ages 55 to 103 years). Our values are higher than other Mediterranean Scots pine forests in central Spain (Santa Regina and Tarazona 2001: $152 \mathrm{Mg} \mathrm{ha}^{-1}$ for stand age 50 years). The reason for the higher biomass accumulated is likely the higher precipitation and milder winter and summer temperatures in our research sites compared to the cited works (Santa Regina and Tarazona 2001).

Baseline scenarios showed a clear drop in ecosystem $\mathrm{C}$ as consequence of the stand-replacing wildfire. Natural disturbances other than wildfires (i.e. non-stand-replacing windthrow, pests and diseases infestations) are also present in Scots pine forests. However, they commonly cause patchy and limited mortality at stand level, and rarely cause the replacement of the whole stand (Hódar et al. 2003, Langstrom and Hellqvist 1993). Therefore, the effects of non-stand-replacing disturbances such as windthrow, insects, diseases or climate change were not included to avoid increasing complexity unnecessarily (Kimmins et al. 2008).

Model estimations for total cereal biomass were lower than observed for nowadays crops in the region. In

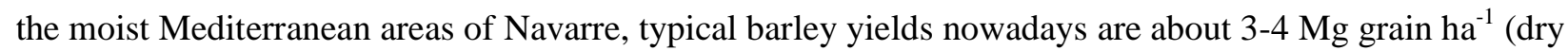
weight) (Goñi and Segura 2012). Modern barley varieties had a typical yield of $0.45 \mathrm{~kg}$ grain $/ \mathrm{kg}$ aerial biomass and a root/shoot biomass ratio of 0.21 (Guzmán et al. 2014). Therefore, typical current biomass in field conditions could be in the range of $8.1-10.8 \mathrm{Mg} \mathrm{ha}^{-1}$. Hence, lower model estimations are expected given the lower technological level in marginal crops by late- $19^{\text {th }}$ century / early $20^{\text {th }}$ century in Spain. Modern barley varieties also had stems shorter than varieties used in the past to prevent lodging and therefore higher root/shoot biomass ratios. For example, Apostolides et al. (2008) estimated $1.6 \mathrm{Mg} \mathrm{ha}^{-1}$ as the average barley grain yield in the late-19 ${ }^{\text {th }}$ century at national level in England, whereas it has been $5.8 \mathrm{Mg} \mathrm{ha}^{-1}$ for the 20002014 period (DEFRA 2014). 
With an average tuber/total biomass ratio of 0.6 (Silva et al. 2013), the average potato productivities in the last twenty years at national level in Spain correspond to $30-48 \mathrm{Mg} \mathrm{ha}^{-1}$ total potato biomass (INE 2014). Therefore, current potato production values are higher than those estimated by the model. Such difference is likely due to the higher potato yields reached in the last decades compared to the productivity that could be expected by the mid-50s in mountain areas (less productive cultivars, no irrigation, scarce fertilization, and mechanization), and also to the location of most potato producing areas in low-lying fertile sites nowadays. As for pasture biomass, model estimations were inside the range reported in a database of grassland productivity in the Pyrenees (Canals and San Emeterio, unpub. data).

The weakest component of the model calibration was the forest understory vegetation, which traditionally has received less attention than trees. Only scarce and disperse documentation is available for understory biomass in mature forests at these sites, which also have a high variability of understory cover (García et al. 2007). Therefore, calibrating the understory component comprised a large degree of uncertainty. However, the estimated maximum understory biomass $\left(2.3 \mathrm{Mg} \mathrm{ha}^{-1}\right)$ is similar to the understory biomass reported by Arias Cuenca (2014) in a Scots pine forest in the western Pyrenees.

\subsection{Changes in $N$ and $C$ pools}

Although in some situations even-age conifer stands can be more productive than uneven-age pristine forests, our results agree with previous observations on a tendency for greater $\mathrm{C}$ storage in unmanaged, multilayered forests relative to those managed (Blanco and González 2010, Harmon et al. 1990, Keith et al. 2009). The clearing and farming of these forest ecosystems had a clear effect in C storage, by substituting large organisms such as trees by small plants such as pastures or crops. This has also been the general trend worldwide since 1850 (Houghton 2012). More importantly, SOM and litter quality were also reduced (Figure $3 \mathrm{~b}-\mathrm{c})$. With changes in land use, low quality litter inputs such as conifer needles with relative low $\mathrm{N}$ concentrations were substituted by litter from annual or perennial herbs with higher $\mathrm{N}$ concentrations and lower lignin content and therefore more labile, which translated into faster decomposition rates and shorter turnover times.

Most of the reduction of the SOM pools in the historical scenarios was achieved in the first 75 years of the simulations, corresponding approximately to the 1850-1925 period. This intensive period of SOM losses has also been identified before for the USA (Houghton and Heckler 2000) and Europe (Kaplan et al. 2012). During the second half of the simulations SOM remained stable at low levels, even after 50 years of tree regrowth. Similar time frames for legacy effects of former management practices have been reported for Swiss Alpine forests (Gimmi et al. 2013) and for European croplands (Ciais et al. 2011).

Reductions in SOM were caused by two main processes: 1) the reduction of litterfall inputs into the soil as the valuable biomass from crops was exported from the ecosystem when harvesting, and 2) the active management and site preparation of lands for farming, which involved slash burning after clearing the land from trees (with its associated $\mathrm{N}$ losses in volatilization), burning after the end of fallow to control weeds, and ploughing, to increase soil oxygenation and therefore increasing SOM mineralization. Differences in N cycle among farming options led to open (in crops) or closed (in pastures) cycles. The former leads to exports by harvested materials, and the later to on-site recycling by animal droppings (Sharro and Ismail 2004). After 
agricultural abandonment there was no noticeable increase in soil $\mathrm{N}$, although there was an increase in ecosystem $\mathrm{C}$, leading to an increase of the $\mathrm{C} / \mathrm{N}$ ratio at ecosystem level. Similar trends have been reported in a chronosequence study of agricultural abandonment in eastern USA (Hooker and Compton 2003). Our results showed that such pronounced declines through time can be only partially recovered after grassland abandonment

On the other hand, the decline in ecosystem $\mathrm{C}$ and $\mathrm{N}$ at the high elevation site stopped after grassland abandonment, but do not show a noticeable increase of these stocks. This phenomenon could have two causes. First, the low fertility sites are more easily pushed through an ecological threshold of non-return by human activities, in which the ecosystem losses its productivity potential and cannot recover to the previous state (Blanco 2012, Shi et al. 2013, Tzanopoulos et al. 2007). Second, in sub-Mediterranean montane sites the presence of strongly competitive shrubs can produce establishment of woody vegetation, but can delay tree regeneration (Debussche and Lepart 1992). Shrublands can also be maintained by human intervention if combined with other uses such as grazing or firewood collection. However, comparing the model estimations to the field data for the low elevation site (Figure 3c), it seems possible to increase $\mathrm{C}$ sinks in vegetation with adequate forest management, rather than relaying only on natural forest regeneration.

At stand level, all these processes caused a C deficit in the range of $378-427 \mathrm{Mg} \mathrm{C}^{-1}$. Such changes are of bigger magnitude than the ones reported for the Alps (Tappeiner et al. 2008) and the eastern USA (Hooker and Thompson 2003), probably because those studies did not include changes in SOM. The regional implications of such $\mathrm{C}$ deficits are difficult to estimate, as statistics on how much land has been abandoned in the Pyrenees are scarce and fragmented. However, in the Spanish westernmost Pyrenean province (Navarre) mountain valleys account for 158,035 ha. In the Pyrenees, it is estimated that about $62 \%$ of this surface is below 1,600 m.a.s.l. (the altitude limit for farming). Lasanta-Martínez (2002) estimated that a very large proportion of this area (on average $28 \%$ ) was used for agriculture in the first half of the $20^{\text {th }}$ century. Since then, an average of $75 \%$ of the land has been abandoned (Lasanta-Martínez 2002). This means that our estimates of $\mathrm{C}$ deficit could be representative of around 20,650 ha in Navarre alone, bringing the provincial deficit to $7.8-8.8 \mathrm{Tg}$ of "missing C", or equivalent to $1.5-1.8$ years of province total $\mathrm{CO}_{2}$ emissions at current rates (Gobierno de Navarra 2014). Similarly, losses of 60\% of SOM due to forest conversion into agriculture have been reported in the Regio Emilia (northern Italy), accounting for a loss of $5 \mathrm{Tg}$ of $\mathrm{C}$ for the period 1935-1990 due to land-use change (Gardi and Sconosciuto 2007). In addition, the French (northern) side of the Pyrenees, which shares many ecological and cultural features with its Spanish counterpart, has been identified as one of the areas owing the soils with the highest $\mathrm{C}$ deficit in France (Angers et al. 2011). As for $\mathrm{N}$, with a deficit at stand level of $4.0-4.6 \mathrm{Mg} \mathrm{N} \mathrm{ha}^{-1}$, an estimated range of $82.8-95.8 \mathrm{Gg} \mathrm{N}$ may have been lost from the forests during land use processes in the last century and a half.

Results for pastures matched previous pan-European modelling exercises, which have estimated that the conversion from arable to grassland could lead to an increase up to $10 \mathrm{Mg}$ soil C ha $^{-1}$ in 50 years (Lugato et al. 2014). Our result was likely due to the almost closed circulation of nutrients and biomass in this system, as most of the pasture biomass is consumed on site by the sheep, which then returns most of the biomass and nutrients to the soil with their droppings (Sharro and Ismail 2004). As a result, nutrient cycles are quite conservative in traditional pasture systems, with available $\mathrm{N}$ much higher for pasture than for crops and even similar to forests in the high elevation site (Figure 4). On the other hand, it has been reported that $\mathrm{C}$ 
sequestration rates in mountain grasslands and crops could be similar or even higher than in forests (Farley et al. 2013, Guidi et al. 2014) depending on site quality, management practices (Post and Kwon 2006) and climate (Berthing et al. 2012). Therefore, the adequacy of each type of land use management in climate change mitigation plans would depend not only on the capacity for storing $\mathrm{C}$ and how it would be influenced by climate change, but also on the previous land use history and the fate of the goods produced.

It is important to distinguish between the potential for long-term $\mathrm{C}$ storage in the two main reservoirs in the ecosystem (Wei and Blanco 2014). Vegetation C, and specially tree C, can be lost by disturbances such as fires, droughts, pests or unsustainable management, whereas soil $\mathrm{C}$ is more stable and resilient. Some of these disturbances are expected to increase in frequency in this region in the medium to long term due to climate change (Bronchalo et al. 2011). Rather than reforesting or letting the forest to naturally recolonize the abandoned farmland, a mosaic of pastures and forests could be more resilient to disturbances by reducing the rate of fire or pest spread or the water demand at landscape level. At the same time, it will also have more value for other uses such as recreation, biodiversity or gaming, among others.

\subsection{Model limitations and further work}

Our work has been a first attempt in the Pyrenees region to estimate the magnitude of the historical regional changes in $\mathrm{C}$ and $\mathrm{N}$ pools. However, as in any modelling exercise, there are several sources of uncertainty (Harmon et al. 2015). First, data used for model calibration mostly came from publications that did not report measurement and sampling errors, and therefore we were not able to estimate the uncertainty associated to parameter calibration. Second, data on forest condition previous to agricultural expansion into the mountain areas (early $19^{\text {th }}$ century) is basically non-existent, and prevented us from quantifying model uncertainty. Here we have used as proxies forests that could be in an almost steady-state as a result of non-human intervention. However, the actual forests have been managed in one way or another for almost 2,000 years. Such management (except during the late Middle Age population peak) would have been sporadic and of low intensity. Hence, just by collecting firewood the amount of coarse woody debris present had likely been lower than the one estimated here for the beginning of the baseline scenarios, and therefore the actual initial SOM pools could have been lower as well (Josefsson et al. 2010). However, the similarity between the field data on ecosystem $\mathrm{C}$ and the model estimates for the high elevation site (Figure 3a) is encouraging that the former uncertainty source is likely negligible. A preliminary model sensitivity analysis for the same sites indicated that FORECAST is relatively robust to uncertainty in belowground-related parameters, with differences up to $\pm 15 \%$ in estimated SOM and available $\mathrm{N}$ at stand age 80 years (Gárate and Blanco 2013).

In addition, there is no information available on crop yields for these marginal sites in the late- $19^{\text {th }}$ century and early $-20^{\text {th }}$ century. If crops were more productive than estimated, drops in nutrient pools by harvest exports would have been probably higher, although the lowest point reached in $\mathrm{C}$ and $\mathrm{N}$ pools would have been very similar to the one estimated here. $\mathrm{C}$ deficits, therefore, would have been of similar value. The model itself has two limitations to properly assess crops and pastures. First, soil erosion is not simulated, as the model focusses on nutrient cycling rather than in soil mass (see section 2.1). Soil erosion, however, could be important in abandoned farmland after planting crops, especially in steep slopes. Not accounting for erosion may have underestimated the rate of fertility losses during the crop simulations. Nonetheless, soil erosion is greatly reduced by a continuous plant cover such as in pastures (Molinillo et al. 1997), and the traditional use 
terraces, as traditionally has been done in the Pyrenees. The similarity of observed and estimated soil C in the low elevation site (Figure 3b) could indicate that this issue is likely minor. Second, FORECAST's annual time step prevents from simulating multiple mowing or grazing events in the same year. Therefore, pasture production was probably underestimated, and therefore $\mathrm{C}$ and $\mathrm{N}$ pools during this period could have been higher. However, when taking into account the whole 150 year period, such limitations would not have affected the magnitude of final $\mathrm{C}$ and $\mathrm{N}$ deficits.

Finally, a limitation of FORECAST is the lack of explicit weather simulation, and particularly of moisture regime. The hybrid approach used in this model assumes that the best way to estimate future growth is to use data on past tree growth, assuming that climate is stable during the simulated period. However, this assumption may not be valid if future climate differs from the past. We think this is not an issue in this particular set of simulations as we are trying to recreate the past. However, for simulations of future climate regimes it will be necessary to include an explicit representation of moisture limitation.

A possible way to address these limitations and to quantify model selection uncertainty (Harmon et al. 2015) could be expanding FORECAST into a daily time step and explicitly simulate soil layers. We are currently in the process to test a new version of FORECAST which includes meteorological data as input and days as simulation time step (Kimmins et al. 2010). Another option could be to use a meta-modelling approach (Blanco 2012) in which a model developed for pastures, such as GRAZPLAN (Moore et al. 1997) or AGPASTURE ( $\mathrm{Li}$ et al. 2011) generates simulation data that are then linked to FORECAST. Using a battery of ecosystem-level process-based models to generate an ensemble of model predictions for the same scenarios (Wang et al. 2014), could also be another option to estimate model selection uncertainty. All things considered, our quantitative estimations should be taken with caution, although the temporal patterns are likely representative of the historical changes in $\mathrm{C}$ and $\mathrm{N}$ pools in the Pyrenees in the last 150 years.

\section{Conclusions and management implications}

If effective mitigation plans to increase fixation of atmospheric $\mathrm{CO}_{2}$ need to be set in place in the near future as a way to fight climate change, it is important to know "what is missing" so the real dimension of how much $\mathrm{C}$ could be added arises. Although in some areas natural processes such as forest expansion after cropland abandonment will bring back some of the lost $\mathrm{C}$ pools, in others it will be necessary to act if the ecosystem productive capacity has been lost.

Even though our quantitative estimations should be taken with caution, we can conclude that the gradual disappearance of the ecological legacy of SOM in forest soils overrides other effects of land use changes on C pools. In addition, pastures seem to have been a better option than crops to stabilize, or at least to slow down, the loss of this ecological legacy. Therefore, any management trying to reduce this $\mathrm{C}$ deficit should focus on incorporating $\mathrm{C}$ in the soils. Some of these measures could be sodding crops with high levels of root biomass or leaf residue, applying livestock manure, adding compost or biochar amendments, reducing tillage, and controlling erosion (Lal 2004, Schmidt et al. 2011). For N pools, the dimension of how much is missing can also indicate how much these ecosystems could sequester before being saturated. Knowing such data has implications for both environmental pollution and climate change mitigation, as it can better frame the ecosystem potential to absorb $\mathrm{N}$ deposition and to support vegetation growth and therefore $\mathrm{C}$ sequestration.

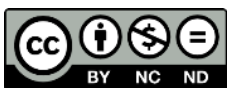


Managing mountain landscapes for climate change mitigation should be done in the framework of human population needs and uses. In regions such as southern Europe, even in relatively isolated mountains like the Pyrenees, human management has a long history that has imprinted large changes in ecosystem structure and function. Some changes have been done along wide temporal and spatial scales, and as a consequence they are not noticed as "unnatural" by most of the population. For this purpose, our research demonstrates the utility of ecosystem-level ecological models as tools to study the likely historical changes through time in the absence of actual historical data.

\section{Acknowledgments}

Funding for this research has been provided by the Spanish Ministry of Economy and Competitiveness (project AGL2012-33465), which also funded Yueh-Hsin Lo. Juan A. Blanco was funded through a Ramón y Cajal contract (ref. RYC-2011-08082) and a Marie Curie Action (ref CIG-2012-326718-ECOPYREN3). Ester González de Andrés was funded through a Spanish Predoctoral Research Grant (ref. BES-2013-066705).

\section{References}

Agren, G.I., Bossata, E. 1996. Theoretical Ecosystem Ecology. Understanding elements cycles. Cambridge University Press, Cambridge.

Álvarez-Sánchez, E., Etchevers, D., Ortiz, J., Núñez, R., Volke, V., Tijerina, L., Martínez, A. 1999. Biomass production and phosphorus accumulation of potato as affected by phosphorus nutrition. J. Plant Nutrition, 2, 205-217.

Álvaro-Fuentes, J., Easter, M., Cantero-Martínez, C., Paustian, K. 2011, Modelling soil organic carbón stocks and their changes in the northeast of Spain. Eur. J. Soil Sci. 62, 685-695.

Andrèn, O., Kätterer, T., 2001. Basic principles for soil carbon sequestration and calculating dynamic countrylevel balances including future scenarios, in: Lal, R., Kimble, J.M., Follett, R.M., Stewart, B.A., (Eds.), Assessment Methods for Soil Carbon. Lewis Publishers, Boca Ratón.

Angers, D.A., Arrouays, D., Saby, N.P.A., Walter, C. 2011. Estimating and mapping he carbon saturation deficit of French agricultural topsoils. Soil Use Manage. 27, 448-452.

Apostolides, A., Broadberry, S., Campbell, B., Overton, M., Van Leeuwen, B. 2008. English agricultural output and labour productivity, 1250 - 1850: some preliminary estimates. University of Warwick, Unpublished Working paper. Available online: www2.warwick.ac.uk/fac/soc/economics/staff/faculty/broadberry/wp/agriclongrun4.pdf.

Araya, A., Habtu, S., Hadgu, K.M., Kebede, A., Dejene, T. 2010. Test of AquaCrop model in simulating biomass and yield of water deficient and irrigated barley (Hordeum vulgare). Agri. Water Manage. 97, 1838-1846.

Arias Cuenca, M. 2014. Influencia a largo plazo de las claras forestales en el sotobosque de bosques de pino del Pirineo navarro: observaciones tras 13 años. BSc thesis. Public University of Navarre, Pamplona,

Artázcoz, R. 2014. Results from a thinning experiment in a natural scots pine stand in the Navarre Pyrenees. BSc. thesis (in Spanish). University of León. León, Spain.

Ballard, T.M. 2000. Impacts of forest management on northern forest soils. For. Ecol. Manage. 133, 37-42. Berthrong, S.T., Piñeiro, G., Jobbagy, E.G., Jackson, R.B. 2012. Soil C and N changes with afforestation of grasslands across gradients of precipitation and plantation age. Ecol. App. 22, 76-86. 
Bi, J., Blanco, J.A., Kimmins, J.P., Ding, Y., Seely, B., Welham, C. 2007. Yield decline in Chinese Fir plantations: A simulation investigation with implications for model complexity. Can. J. For. Res. 37, 1615-1630.

Blanco, J.A. 2004. The practice of forest thinning and its influence on nutrient cycling in two Scots pine stands in the Pyrenees of Navarre. PhD Thesis, Public University of Navarre, Pamplona.

Blanco J.A. 2012. Más allá de los modelos de crecimiento: modelos ecológicos híbridos en el contexto del manejo forestal sostenible. Cuadernos de la Sociedad Española de Ciencias Forestales 34, 11-25.

Blanco J.A. 2012. Forests may need centuries to recover their original productivity after continuous intensive management: an example from Douglas-fir. Sci. Tot. Environ. 437, 91-103.

Blanco, J.A., González, E. 2010. Exploring the sustainability of current management prescriptions for Pinus caribaea plantations in Cuba: a modelling approach. J. Trop. For. Sci. 22, 139-54.

Blanco, J.A., Imbert, J.B., Castillo, F.J. 2006a. Influence of site characteristics and thinning intensity on litterfall production in two Pinus sylvestris L. forests in the Western Pyrenees. For. Ecol. Manage. 237, 342-352.

Blanco, J.A., Imbert, J.B., Castillo, F.J. 2006b. Effects of thinning on nutrient pools in two contrasting Pinus sylvestris L. forests in the western Pyrenees. Scan. J. For. Res. 21, 143-150.

Blanco, J.A., Imbert, J.B., Castillo, F.J., 2011. Thinning affects Pinus sylvestris needle decomposition rates and chemistry differently depending on site conditions. Biogeochemistry 106, 397-414.

Blanco, J.A., Seely, B., Welham, C., Kimmins, J.P., Seebacher, T.M. 2007. Testing the performance of FORECAST, a forest ecosystem model, against 29 years of field data in a Pseudotsuga menziesii plantation. Can. J. For. Res. 37, 1808-1820.

Blanco, J.A., Wei, X., Jiang, H, Jie, C.Y., Xin, Z.H. 2012. Enhanced nitrogen deposition in south-east China could partially offset negative effects of soil acidification on biomass production of Chinese fir plantations. Can. J. For. Res. 42, 437-450.

Blanco, J.A., Zavala, M.A., Imbert, J.B., Castillo, F.J. 2005. Sustainability of forest management practices: Evaluation through a simulation model of nutrient cycling. For. Ecol. Manage. 213, 209-228.

Bronchalo, E., Gutiérrez-Teira, A., Picatoste, J.R., Sánchez, G. 2011. Impactos, Vulnerabilidad y Adaptación al Cambio Climático en el Sector Forestal. Ministerio de Medio Ambiente y Medio Rural y Marino. Madrid.

Canals, R.M., Pedro, J., Rupérez, E., San-Emeterio, L. 2014. Nutrient pulses after prescribed winter fires and preferential patterns of $\mathrm{N}$ uptake may contribute to the expansion of Brachypodium pinnatum ( L.) Beauv in highland grasslands. App. Veg. Sci. 17, 419-428.

Castrillón, Y., Blanco, J.A., Primicia, I., Ansó, M., Imbert, J.B., Castillo, F.J. 2013. Evaluation of the ecological model FORECAST to simulate litter production in pine stands in the Pyrenees. 11th Congress of the AEET: invitation to Ecology: strengthening links with Society Pamplona, May 6-10 ${ }^{\text {th }}$.

Chertov, O.G., Komarov, A.S., Nadporozhskaya, M., Bykhovets, S.S., Zudin, S.L., 2001. ROMUL — a model of forest soil organic matter dynamics as a substantial tool for forest ecosystem modeling. Ecol. Model. 138, 289-308.

Chocarro, C., Fanlo, R., Fillat, F., Marín, P. 1990. Historical evolution of natural resource use in the Central Pyrenees of Spain. Mountain Res. Devel. 10, 257-265.

Ciais, P., Gervois, S., Vuichard, N., Piao, S.L., Viovy, N., 2011. Effects of land use change and management on the European cropland carbon balance. Glob. Change Biol. 17, 320-338. 
Debussche, M., Lepart, J. 1992. Establishment of Woody plants in Mediterranean old fields: opportunity in space and time. Land. Ecol. 6, 133-145.

Department for Environment, Food and Rural Affairs. 2014. Observatory monitoring framework - indicator data sheet, Process: Farm Business, Indicator B11: Crop and Milk Yields. UK Government. Available at https://www.gov.uk/government/uploads/system/uploads/attachment data/file/326713/agindicator-b11$\underline{03 j u l 14 . p d f}$

Dixon, R.K., Brown, S., Houghton, R.A., Solomon, A.M., Trexier M., Wisniewski, J. 1994. Carbon pools and flux of global forest ecosystems. Science 263, 185-191.

Dordas, C. 2012. Variation in dry matter and nitrogen accumulation and remobilization in barley as affected by fertilization, cultivar, and source-sink relations. Eur. J. Agron. 37, 31-42.

Duke, J.A. 1983. Hordeum vulgare L. Handbook of Energy Crops. Purdue University, Center for New Crops \& Plants Products, Lafayette.

Farley, K.A., Bremer, L.L., Harden, C.P., Harstig, J. 2013. Changes in carbon storage under alternative land uses in biodiverse Andean grasslands: implications for payment for ecosystem services. Conserv. Let. 6, 21-27.

Fernández, M., 2013. Effect of the tree species and forest management on the soil capacity for water interception. MSc thesis (in Spanish). University of the Basque Country. Leioa.

Fisher, R.F., Binkley, D. 2000. Ecology and Management of Forest Soils, 3rd edition, Wiley: New York.

Gárate M., Blanco J.A. 2013. Importance of root biomass characterization when simulating forest ecosystems. Ecosistemas 22, 66-73.

García Del Barrio, J.M. 2000. Compartimentos y flujos de biomasa y nutrientes en un pinar de Pinus sylvestris L. en el monte de Valsaín. Monografias INIA: Serie Forestal 2, Madrid.

García, J.L., Tella, G. 1983. Tablas de producción de densidad variable para Pinus sylvestris L. en el sistema pirenaico. Comunicaciones INIA. Serie Recursos Naturales, 43, Madrid.

García-Ruiz, J.M., Lasanta-Martínez, T. 1990. Land-Use changes in the Spanish Pyrenees. Mountain Res. Devel.10, 267-269.

Gardi, C., Sconosciuto, F. 2007. Evaluation of carbon stock variation in Northern Italian soils over the last 70 years. Sustain. Science 2, 237-243.

Gimmi, U., Poulter, B., Wolf, A., Portner, H., Weber, P., Bürgi, M., 2013. Soil carbon pools in Swiss forests show legacy effects from historic forest litter raking. Land. Ecol. 28, 835-846.

Gobierno de Navarra. 2014. Informe de estado de medio ambiente. Gobierno de Navarra, Pamplona.

Gómez Mercado, R., Ortiz Solorio, C.A., Zamora Díaz, M., Soria Ruiz, J., Trinidad Santos, A., Carballo Carballo, A. 2009. Estimation of malting barley (Hordeum vulgare L.) yield by the FAO method. Agricultura Técnica en México 35, 13-23.

Goñi, J., Segura, A. 2012. Nuevas variedades de cereal: resultados de la experimentación en la campaña 20112012, recomendaciones para la campaña 2012-2013. Navarra Agraria 194, 11-20.

Gracia, M., Montané, F., Piqué, J., Retana, J. 2007. Overstory structure and topographic gradients detremining diversity and abundance of understory shrub species in temperate forests in central Pyrenees (NE Spain). For. Ecol. Manage. 242, 391-397.

Guidi, C., Vesterdal, L., Gianelle, D., Rodeghiero, M. 2014. Changes in soil organic carbon and nitrogen following forest expansion on grassland in the Southern Alps. For. Ecol. Manage. 328, 103-116. 
Guzmán, G.,, Aguilera, E., Soto, D., et al. 2014. Methodology and conversion factors to estimate the net primary productivity of historical and contemporary agroecosystems. Sociedad Española de Historia Agraria, Documento de Trabajo DT-SEHA n 1407, Seville.

Harmon, M.E., Ferrel, W.K., Franklin, J.F. 1990. Effects on carbon storage of conversion of old-growth to young forests. Science 247, 699-702.

Harmon M.E., Fasth, B., Halpern, C.B., Lutz, J.A. 2015. Uncertainty analysis: an evaluation metric for synthesis science. Ecosphere 6, article 63.

Hashimoto, S., Wattenbach, M., Smith, P. 2011. A new scheme for initializing process-based ecosystem models by scaling soil carbon pools. Ecol. Model. 222, 3598-3602.

Herold, M., Román-Cuesta, R.M., Heymell, V., Hirata, Y., Van Laake, P., Asner, G.P., Souza, C., Avitabile, V., MacDicken, K. 2011. A review of methods to measure and monitor historical carbon emissions from forest degradation. Unysilva 238, 16-24.

Hódar, J.A., Castro, J., Zamora, R. 2003. Pine processionary Caterpillar Thaumetopoea pityocampa as a new threat for relict Mediterranean Scots pine under climatic warming. Biol. Conserv. 110, 123-129.

Hooker, T.D., Compton, J.E. 2003. Forest ecosystem carbon and nitrogen accumulation during the first century after agricultural abandonment. Ecol. App. 13, 299-313.

Houghton, R.A. 2012. Historical changes in terrestrial carbon storage, in: Lal, R., Lorenz, K., Hütll, R.F., Schneider, B.U., von Braun, J. (Eds) Recarbonization of the biosphere: Ecosystems ad the global carbon cycle. Springer, Dordrecht.

Houghton, R.A., Heckler, J.L. 2000. Changes in terrestrial carbon storage in the United States .1: The roles of Agriculture and Forestry. Glob. Ecol. Biogeo. 9, 125-144.

Imbert, B., Blanco, J.A., Castillo, F. 2008. Gestión forestal y ciclo de nutrientes en el marco del cambio global, in :Valladares, F., (ed.) Ecología del bosque mediterráneo en un mundo cambiante, second edition Ministerio de Medio Ambiente / EGRAF S.A., Madrid.

Instituto Nacional de Estadística. 2014. Superficie, rendimiento y producción agrícola. Datos europeos. Available online: http://www.inie.es

Iriarte, A., Puertas, F. 2003. Thinning experiment in a natural stand of Pinus sylvestris L., Aspurz (Navarre). In Proceedings of IUFRO meeting "Silviculture and sustainable management in mountain forests in the western Pyrenees. Isaba. 15-19 Sep 2003.

Josefsson, T., Olsson, J., Östlund, L. 2010. Linking forest history and conservation efforts: Long-term impact of low-intensity timber harvest on forest structure and wood-inhabiting fungi in northern Sweden. Biol. Conserv. 143, 1803-1811.

Kaplan, J.O., Krumhardt, K.M., Zimmermann, N.E., 2012. The effects of land use and climate change on the carbon cycle of Europe over the past 500 years. Glob. Change Biol. 18, 902-914.

Keith, H., Mackey B.G., Lindenmayer D.B. 2009. Re-evaluation of forest biomass carbon stocks and lessons from the world's most carbon-dense forests. PNAS 106, 11635-11640.

Kimmins, J.P. 1997. Balancing Act: environmental issues in forestry, second ed., University of British Columbia Press: Vancouver..

Kimmins, J.P. 2004. Forest Ecology. A foundation for sustainable management and environmental ethics in forestry. Prentice Hall: New Jersey.

Kimmins, J.P. 1993. Scientific foundations for the simulation of ecosystem function and management in FORCYTE-11. For. Can. Northwest Reg., North. For. Cent., Inf. Rep. NOR-X-328. Edmonton. 
Kimmins, J.P., Mailly, D., Seely, B. 1999. Modelling forest ecosystem net primary production: the hybrid simulation approach use in FORECAST. Ecol. Model. 122, 195-224.

Kimmins, J.P., Blanco, J.A., Seely, B., Welham, C., Scoullar, K. 2008. Complexity in Modeling Forest Ecosystems, How Much is Enough? For. Ecol. Manage. 256, 1646-1658.

Kimmins, J.P., Blanco, J.A., Seely, B., Welham, C., Scoullar, K. 2010. Forecasting Forest Futures: A Hybrid Modelling Approach to the Assessment of Sustainability of Forest Ecosystems and their Values. Earthscan Ltd.: London.

Kolbe, H., Stephan-Beckmann, S. 1997a. Development, growth and chemical composition of the potato crop (Solanum tuberosum L.). I. Leaf and stem. Potato Res. 40, 111-129.

Kolbe, H., Stephan-Beckmann, S. 1997b. Development, growth and chemical composition of the potato crop (Solanum tuberosum L.). II. Tuber and whole plant. Potato Res. 40, 135-153.

Lal, R. 2004. Soil carbon sequestration to mitigate climate change. Geoderma 123, 1-22.

Landsberg, J. 2003. Modelling forest ecosystems: state of the art, challenges, and future directions. Can. J. For. Res. 33, 385-397.

Langstrom, B., Hellqvist, C. 1993. Induced and spontaneous attacks by pine shoot beetles on your Scots pine trees: tree mortality and beetle performance. J. App. Entomol.115, 25-36.

Lasanta-Martínez, T. 2002. Los sistemas de gestión en el Pirineo central español durante el siglo XX: del aprovechamiento global de los recursos a la descoordinación espacial en los usos del suelo. Ager 2, 173195.

Li, F.Y., Snow, V.O., Holzworth, D.P. 2011. Modelling the seasonal and geographical pattern of pasture production in New Zealand. New Zea. J. Agr. Res.54, 331-352.

Lugato, E., Bampa, F., Panagos, P., Montanarella, L., Jones, A. 2014 Potential carbon sequestration of European arable soils estimated by modelling a comprehensive set of management practices. Glob. Change Biol. 20, 3557-3567.

Marley, C.L., Fychan, R., Theobald, V.J., Cuttle, S.P., Sanderson, R. 2013. Effects of a winter or spring sowing date on soil nitrogen utilization and yield of barley following a forage crop of red clover Lucerne or hybrid ryegrass. Agr. Ecosys. Environ. 181, 213-222.

Martínez, C. 2015. Thinning influence on coarse Woody debris production in pine forests in the Navarrean Pyrenees. MSc thesis (in Spanish). Public University of Navarre. Pamplona.

Mitchell, R.J., Auld, M.H.D., Hughes, J.M., Marrs, R.H. 2000. Estimates of nutrient removal during heathland restoration of successional sites in Dorset, southern England. Biol. Conserv. 95, 233-246.

Molinillo, M., Lasanta, T., García-Ruiz, J.M. 1997. Managing mountainous degraded landscapes after farmland abandonment in the Central Spanish Pyrenees. Environ.Manage. 21, 587-598.

Moore, A.D., Donnelly, J.R., Freer, M. 1997. GRAZPLAN: Decision support systems for Australian grazing enterprises. III. Pasture growth and soil moisture submodels and the GrassGro DSS. Agri. Syst. 55, 535582.

Morris, D.M., Kimmins, J.P., Duckert, D.R. 1997. The use of soil organic matter as a criterion of the relative sustainability of forest management alternatives: a modelling approach using FORECAST. For. Ecol. Manage. 94, 61-78.

Oliver, C.D., Larson, B.C. 1996. Forest stand dynamics: Update edition, Wiley: New York.

Parton, W.J., Schimel, D.S., Cole, C.V., Ojima, D.S., 1987. Analysis of factors controlling soil organic matter levels in Great Plains grasslands. Soil Sci. Soc.Am. J. 51, 1173-1179. 
Pausas, J., Fons, J.G. 1992. Estructura y crixement d'algunes pinedes en diferents situacionst opogràfiques. Folia Botanica et Miscelanea, 8, 199-213.

Penman, J., Gytarsky, M., Hiraishi, T., Krug, T., Kruger, D., Pipatti, R., Buendia, L., Miwa, K., Ngara, T., Tanabe, K., Wagner, F.. 2003. Good Practice Guidance for Land Use, Land-Use Change and Forestry. IPCC National Greenhouse Gas Inventories Programme and Institute for Global Environmental Strategies, Kanagawa.

Pérez de Ciriza, J.J., Yanguas, R., Delgado, J., Carro, P. 2007. Sistemas de laboreo en zonas cerealistas: producción según zonas. Navarra Agraria, 163, 11-16.

Prentice, I.C., Farquhar, G.D., Fasham, M.J.R. et al. 2001. The carbon cycle and atmospheric carbon dioxide. in:, J.T., Ding, Y., Griggs, D.J., et al.,(eds.) Climate Change 2001: the scientific basis. Contributions of Working Group 1 to the Third Assessment Report of the Intergovermental Panel on Climate Change, Houghton Cambridge University Press: Cambridge.

Puertas, F. 2001. Sitios de ensayo de claras de masas de pino Silvestre en Navarra (Garde y Aspurz). Servicio de Conservación de la Biodiversidad. Departamento de Medio Ambiente Ordenación del Territorio y Vivienda. Government of Navarre, Pamplona.

Puertas, F. 2003. Scots pine in Navarre: Economic importance and production, in: Proceedings of the I.U.F.R.O. Meeting "Silviculture and sustainable management in mountain forests in the western Pyrenees". Navarre..

Post, W.M., Kwon, K.C. 2006. Soil carbon sequestration and land-use change: processes and potential. Glob. Change Biol. 6, 317-328.

Puigdefábregas, J., Alvera, B. 1977. Biomasa, producción y desfronde en el pinar con acebo de San Juan de la Peña (Huesca). Publicaciones del Centro Pirenaico de Biología Experimental 8, 23-40.

Rius, D., Vannière, B, Galop, D. 2009. Fire frequency and landscape management in the northwestern Pyrenean piedmont, France, since the early Neolithic (8000 cal. BP). The Holocene 19, 847-859.

Santa Regina, I., Tarazona, T. 2001. Nutrient cycling in a natural beech forest and adjacent planted pine in northern Spain. Forestry 74, 11-28.

Schmidt, M.W.I. et al. 2011. Persistence of soil organic matter as an ecosystem property. Nature 78, 49-56. Sebastià, M.T., Garcia-Pausas, J., Canals, R.M., Plaixats, J., Arco, N., Bartolomé, J., Connolly, J., SanEmeterio, L., Vallecillo, S., Casals, P. 2006. Changes in the carbon and nitrogen cycles with land use in grasslands in the Pyrenees. Grassland Sci. Eur. 11, 769-771.

Seely, B., Welham, C., Blanco, J.A. 2010. Towards the application of soil organic matter as an indicator of ecosystem productivity: deriving thresholds, developing monitoring systems, and evaluating practices. Ecol. Indic. 10, 999-1008.

Sharro, S.H., Ismail, S. 2004. Carbon and nitrogen storage in agroforests, tree plantations, and pastures in western Oregon, USA. Agrofor. Sys. 60, 123-130.

Shi, M., Yang, Z.-L., Lawrence, D., Dickinson, R.E., Subin Z.M. 2013. Spin-up processes in the Community Land Model version 4 with explicit carbon and nitrogen components. Ecol. Model. 263, 308-325.

Silva, J.G., França, M.G.C., Gomide, F.T.F., Magalhaes, J.R. 2013. Different nitrogen sources affect biomass partitioning and quality of potato production in a hydroponic system. Am. J. Potato Res. 90, 179-185.

Spanish Ministry of Environment. 2003. Deposición atmosférica en la estación de Burguete (Navarra). Spanish Ministry of Environment, Servicio de Protección Contra Agentes Nocivos en los Montes: Madrid. 
Steffen, W., Persson, A., Deutsch, L., Zalasiewicz, J., Williams, M, et al. 2011. The Anthropocene: from global change to planetary stewardship. AMBIO 40, 739-761.

Stoatte, C., Boatman, N.D., Borralho, R.J., Rio Carvalho, C., de Snoo, G.R., Eden, P. 2001. Ecological impacts of arable intensification in Europe. J. Environ. Manage. , 63, 337-365.

Tappeiner, U., Tasser, E., Leitinger, G., Cernusca, A., Tappeiner, G. 2008. Effects of historical and likely future scenarios of land use on above- and belowground vegetation carbon stocks of an Alpine valley. Ecosystems 11, 1383-1400.

Terradas, J. 2001. Ecología de la vegetación: De la ecofisiología de las plantas a la dinámica de comunidades y paisajes. Ediciones Omega: Barcelona.

Torrecilla, J.J. 2012. Balance de la campaña cerealista: zonas áridas con baja producción, zonas de montaña y baja montaña con rendimientos históricos. Navarra Agraria 194, 7-10.

Tres, I. 2014. Influencia de las claras forestales en el crecimiento y estructura de un rodal de pino silvestre en el pirineo navarro (in Spanish). BSc. Thesis. Public University of Navarre. Pamplona, Spain.

Tzanopoulos, J., Mitchley, J., Pantis, J.D. 2007. Vegetation dynamics in abandoned crop fields on a Mediterranean island: development of succession model and estimation of disturbance thresholds. Agri. Ecosys. Environ. 120, 370-376.

Vitousek, P.M. 1994. Beyond global warming: Ecology and global change. Ecology 75, 1861-1876.

Walkley, A., Black, .I.A. 1934. An examination of the Degtjareff method for determining soil organic matter and a proposed modification of the chromic acid titration method. Soil Sci. 37, 29-38.

Wang, F., Mladenoff, D., Forrester, J., Blanco, J.A., Scheller, R., Peckham, S., Keough, C. 2014. Multi-model simulations of long-term effects of forest harvesting on ecosystem productivity and $\mathrm{C} / \mathrm{N}$ cycling. Ecol. App. 26, 1374-1389.

Wang, W., Wei, X., Liao, W., Blanco, J.A., Liu, Y., Liu, S., Liu, G., Guo, X., Guo, S. 2013. Evaluation of the effects of forest management strategies on carbon sequestration in evergreen broad-leaved (Phoebe bournei) plantation forests using FORECAST ecosystem model. For. Ecol. Manage., 300, 21-32.

Wei, X., Blanco, J.A. 2014. Significant increase in ecosystem C can be achieved with sustainable forest management in subtropical plantation forests. PLOS One 9, e89688.

Welham, C., Van Rees, K., Seely, B., Kimmins, J.P. 2007. Projected long-term productivity in Saskatchewan hybrid poplar plantations: weed competition and fertilizer effects. Can. J. For. Res. 37, 356-370.

Welham, C., Blanco, J.A., Kimmins, J.P., Seely, B. 2010. The utility and application of ecological models in agroforestry: the FORECAST family of models, in: Kellimore, L.R. (Ed.) Handbook of Agroforestry: Management, Practices and Environmental Impact, Nova Science Publishers: New York.

Welham C., Blanco J.A., Seely B., Bampfylde C. 2012b. Oil sands reclamation and the projected development of wildlife habitat attributes, in: Vitt, D.H., Bhatti, J.S., (Eds.) Reclamation and Restoration of Boreal Ecosystems: attaining sustainable development.Cambridge University Press: Cambridge.

Zalasiewicz, J., Williams, M., Smith, A., Barry, T.L. et al. 2008. Are we now living the Anthropocene? GSA Today 18, 4-8. 
Table 1. Site characteristics (mean \pm standard error). Stand descriptors from Puertas (2001), Iriarte and Puertas (2003), Tres (2014), and Artázcoz (2014).

\begin{tabular}{|c|c|c|c|c|}
\hline Site & \multicolumn{2}{|c|}{ Low elevation (Aspurz) } & \multicolumn{2}{|c|}{ High elevation (Garde) } \\
\hline Latitude & \multicolumn{2}{|c|}{$42^{\circ} 42^{\prime} 31^{\prime \prime} \mathrm{N}$} & \multicolumn{2}{|c|}{$42^{\circ} 48^{\prime} 50^{\prime \prime} \mathrm{N}$} \\
\hline Longitude & \multicolumn{2}{|c|}{$1^{\circ} 8^{\prime} 40^{\prime \prime} \mathrm{W}$} & \multicolumn{2}{|c|}{$52{ }^{\prime} 30 ” \mathrm{~W}$} \\
\hline Altitude (m) & \multicolumn{2}{|c|}{625} & \multicolumn{2}{|c|}{1335} \\
\hline Slope $(\%)$ & \multicolumn{2}{|c|}{7} & \multicolumn{2}{|c|}{40} \\
\hline Mean Temperature $\left({ }^{\circ} \mathrm{C}\right)$ & \multicolumn{2}{|c|}{12.0} & \multicolumn{2}{|c|}{8.2} \\
\hline Mean precipitation $(\mathrm{mm})$ & \multicolumn{2}{|c|}{912} & \multicolumn{2}{|c|}{1268} \\
\hline Climate type (Papadakis, 1970) & \multirow{2}{*}{\multicolumn{2}{|c|}{$\begin{array}{l}\text { Cold wet Mediterranean } \\
\text { Fagus sylvatica L. } \\
\text { Quercus humilis L. }\end{array}$}} & \multicolumn{2}{|c|}{ Cold wet continental } \\
\hline Other overstory tree species ${ }^{\mathrm{a}}$ & & & Fagus sy & $c a \mathrm{~L}$ \\
\hline Site Index at stand age 80 years $(\mathrm{m})$ & \multicolumn{2}{|c|}{29} & \multicolumn{2}{|c|}{23} \\
\hline \multicolumn{5}{|l|}{ Tree inventory data } \\
\hline Year & 1999 & 2014 & 1999 & 2013 \\
\hline Age (y) & 32 & 47 & 37 & 51 \\
\hline Density $\left(\text { stems ha }{ }^{-1}\right)^{b}$ & $4040 \pm 326$ & $1456 \pm 140$ & $3230 \pm 162$ & $2747 \pm 328$ \\
\hline Dominant height $(\mathrm{m})^{\mathrm{c}}$ & $15.1 \pm 0.4$ & $20.4 \pm 0.3$ & $14.3 \pm 0.2$ & $17.3 \pm 0.9$ \\
\hline Mean DBH $(\mathrm{cm})^{\mathrm{d}}$ & $11.7 \pm 0.5$ & $18.9 \pm 1.0$ & $13.8 \pm 0.3$ & $14.85 \pm 0.2$ \\
\hline
\end{tabular}

Table 2. Soil chemical and physical properties in the study sites. Organic matter (O.M.) and organic C defined as in Walkley and Black (1934), Kjeldahl N. Data from Blanco et al. (2011).

\begin{tabular}{llllllllllll}
\hline Site/ & Depth & Clay & Silt & Sand & pH & Density $^{\mathrm{a}}$ & $\mathrm{CEC}^{\mathrm{b}}$ & O.M. & $\mathrm{C}$ & $\mathrm{N}$ & Soil \\
Horizon & $\mathrm{cm}$ & $\%$ & $\%$ & $\%$ & $1: 2.5 \mathrm{H2O}$ & $\mathrm{g} \mathrm{cm}^{3}$ & $\mathrm{meq} \mathrm{100} \mathrm{^{-1 }}$ & $\%$ & $\mathrm{mg} \mathrm{g}^{-1}$ & $\mathrm{mg} \mathrm{g}^{-1}$ & $\mathrm{C} / \mathrm{N}$ \\
\hline
\end{tabular}

Low elevation site (Aspur): Haplic Alisol

Leaf litter

$$
\begin{array}{rrrr}
- & - & - & - \\
0-10 & 7.2 & 50.5 & 42.3 \\
10-45 & 14.2 & 33.3 & 55.5 \\
\text { site (Garde): Dystric Cambisol }
\end{array}
$$

$\begin{array}{ll}5.45 & 0.96 \\ 5.55 & 1.31\end{array}$

$\begin{array}{rr}14.2 & 11.69 \\ 7.2 & 1.14\end{array}$

48.3

1.1243 .1

B

5.55

1.31

67.8

\begin{tabular}{|c|c|c|c|c|c|c|c|c|c|c|c|}
\hline Leaf litter & - & - & - & - & - & - & - & - & 48.6 & 0.86 & 56.5 \\
\hline A & $0-10$ & 23.3 & 30.8 & 45.8 & 5.48 & 0.76 & 23.3 & 9.88 & 57.3 & 2.67 & 22.0 \\
\hline B & $10-45$ & 25.7 & 34.5 & 39.4 & 6.00 & 1.26 & 19.7 & 3.05 & 17.7 & 2.31 & 7.7 \\
\hline $\mathrm{C}$ & $45-60$ & 26.5 & 31.7 & 41.8 & 6.40 & 0.71 & 22.6 & 1.88 & 10.9 & 1.60 & 6.8 \\
\hline
\end{tabular}

$\begin{array}{lll}6.6 & 1.503 & 4.4\end{array}$

High elevation site (Garde): Dystric Cambisol 
Table 3. Values used to calibrate FORECAST parameters related to Scots pine. Nitrogen concentration data were obtained from the research sites.

\section{Parameter}

Nitrogen concentration in needles young / old / dead

Nitrogen concentration in stem sapwood / heartwood

Nitrogen concentration in bark live / dead

Nitrogen concentration in branches live / dead

Nitrogen concentration in root sapwood / heartwood

Nitrogen concentration in fine roots live / dead

Shading by maximum foliage biomass

Soil volume occupied at maximum fine root biomass ${ }^{3}$

Efficiency of $\mathrm{N}$ root capture

Retention time for young / old foliage / dead branches

Fine roots turnover

Maximum foliage biomass

\begin{tabular}{ccc} 
Unit & Low elevation site & High elevation site \\
$\%$ & $1.69 / 1.60 / 1.12$ & $1.24 / 1.18 / 0.86$ \\
$\%$ & $0.11 / 0.09$ & $0.10 / 0.08$ \\
$\%$ & $0.38 / 0.33$ & $0.25 / 0.19$ \\
$\%$ & $0.53 / 0.31$ & $0.35 / 0.11$ \\
$\%$ & $0.53 / 0.31$ & $0.25 / 0.24$ \\
$\%$ & $0.86 / 0.67$ & $0.76 / 0.57$ \\
$\%$ of full light & 40 & 40 \\
$\%$ & 95 & 95 \\
$\%$ & 98 & 98 \\
years & $1 / 2.20 / 12$ & $1 / 2.35 / 17$ \\
year $^{-1}$ & 1.00 & 0.75 \\
Kg tree $^{-1}$ & 37 & 30 \\
\hline
\end{tabular}


Table 4. Values used to calibrate FORECAST parameters related to crops' processes.

\begin{tabular}{|c|c|c|c|}
\hline Potato parameters & Unit & Low elevation site & High elevation site \\
\hline Nitrogen concentration in leaves live / dead & $\%$ & $2.30 / 1.85$ & $2.23 / 1.80$ \\
\hline Nitrogen concentration in stems live / dead & $\%$ & $1.50 / 0.85$ & $1.30 / 0.80$ \\
\hline Nitrogen concentration in rhizomes live / dead & $\%$ & $1.68 / 0.70$ & $1.58 / 0.70$ \\
\hline Nitrogen concentration in roots live / dead & $\%$ & $1.45 / 0.85$ & $1.40 / 0.80$ \\
\hline Shading by maximum foliage biomass & $\%$ of full light & 0.20 & 0.20 \\
\hline Soil volume occupied at maximum fine root biomass & $\%$ & 75 & 75 \\
\hline Efficiency of $\mathrm{N}$ root capture & $\%$ & 99 & 99 \\
\hline Transfer from live to dead stem / rhizomes / roots & $\%$ year $^{-1}$ & $80 / 80 / 80$ & $80 / 80 / 80$ \\
\hline Retention time for foliage & years & 1 & 1 \\
\hline Maximum total biomass (above + belowground) & $\mathrm{Mg} \mathrm{ha}^{-1}$ & 17.32 & 14.16 \\
\hline \multicolumn{4}{|l|}{ Grass parameters } \\
\hline Nitrogen concentration in leaves live / dead & $\%$ & $3.00 / 2.10$ & $2.40 / 1.80$ \\
\hline Nitrogen concentration in stems live / dead & $\%$ & $1.30 / 0.95$ & $1.20 / 0.80$ \\
\hline Nitrogen concentration in rhizomes live / dead & $\%$ & $1.10 / 0.80$ & $0.90 / 0.80$ \\
\hline Nitrogen concentration in roots live / dead & $\%$ & $1.60 / 0.45$ & $1.40 / 0.80$ \\
\hline Shading by maximum foliage biomass & $\%$ of full light & 0.20 & 0.20 \\
\hline Soil volume occupied at maximum fine root biomass & $\%$ & 75 & 65 \\
\hline Efficiency of $\mathrm{N}$ root capture & $\%$ & 99 & 99 \\
\hline Transfer from live to dead stem / rhizomes / roots & $\%$ year $^{-1}$ & $20 / 10 / 50$ & $20 / 10 / 60$ \\
\hline Retention time for foliage & years & 3 & 1 \\
\hline Maximum total biomass (above + belowground) & $\mathrm{Mg} \mathrm{ha}^{-1}$ & 5.0 & 5.5 \\
\hline \multicolumn{4}{|l|}{ Barley parameters } \\
\hline Nitrogen concentration in leaves live / dead & $\%$ & $5.86 / 1.80$ & $5.86 / 1.80$ \\
\hline Nitrogen concentration in stems live / dead & $\%$ & $5.06 / 1.80$ & $5.06 / 1.80$ \\
\hline Nitrogen concentration in rhizomes live / dead & $\%$ & $0.90 / 0.50$ & $0.90 / 0.50$ \\
\hline Nitrogen concentration in roots live / dead & $\%$ & $3.26 / 1.80$ & $3.26 / 1.80$ \\
\hline Shading by maximum foliage biomass & $\%$ of full light & 0.20 & 0.20 \\
\hline Soil volume occupied at maximum fine root biomass & $\%$ & 85 & 80 \\
\hline Efficiency of $\mathrm{N}$ root capture & $\%$ & 99 & 99 \\
\hline Transfer from live to dead stem / rhizomes / roots & $\%$ year $^{-1}$ & $100 / 100 / 100$ & $100 / 100 / 100$ \\
\hline Retention time for foliage & years & 1 & 1 \\
\hline Maximum total biomass (above + belowground) & $\mathrm{Mg} \mathrm{ha}^{-1}$ & 12.27 & 9.37 \\
\hline
\end{tabular}


Table 5. Deficits at the end of the scenarios (beginning of $21^{\text {st }}$ century) in $\mathrm{C}$ and $\mathrm{N}$ pools in the historical scenarios compared to the baseline scenarios.

\begin{tabular}{llllll}
\hline Site & $\begin{array}{l}\text { Ecosystem C } \\
\left(\mathrm{Mg} \mathrm{C} \mathrm{ha}^{-1}\right)\end{array}$ & $\begin{array}{l}\text { Vegetation C } \\
\left(\mathrm{Mg} \mathrm{C} \mathrm{ha}^{-1}\right)\end{array}$ & $\begin{array}{l}\text { Soil C } \\
\left(\mathrm{Mg} \mathrm{C} \mathrm{ha}^{-1}\right)\end{array}$ & $\begin{array}{l}\text { Soil N } \\
\left(\mathrm{Mg} \mathrm{N} \mathrm{ha}^{-1}\right)\end{array}$ & $\begin{array}{l}\text { Available N } \\
\left(\mathrm{kg} \mathrm{N} \mathrm{ha}^{-1}\right)\end{array}$ \\
\hline High elevation & 377.32 & 200.92 & 176.40 & 4.01 & 176.40 \\
Low elevation & 427.95 & 226.92 & 201.03 & 4.64 & 238.86 \\
\hline
\end{tabular}

Table 6. Relative changes (\%) in $\mathrm{C}$ and $\mathrm{N}$ pools caused by different management types. Values indicate percentage of change comparing final and initial values.

\begin{tabular}{llllll}
\hline Site & Management type & Years & Ecosystem C & Soil C & Soil N \\
\hline Low elevation & $1^{\text {st }}$ Pasture & $1-25$ & -19.53 & -19.18 & -17.06 \\
& Cereal & $26-50$ & -20.95 & -20.17 & -17.59 \\
& Potato & $51-75$ & -12.46 & -10.34 & -9.68 \\
& $2^{\text {nd }}$ pasture & $76-100$ & -11.66 & -13.21 & -11.56 \\
& Abandonment & $101-150$ & 69.49 & 1.82 & -1.35 \\
& & & & & \\
High elevation & $1^{\text {st }}$ Pasture & $1-50$ & -21.44 & -22.65 & -18.15 \\
& Cereal & $51-75$ & -24.15 & -23.60 & -20.74 \\
& $2^{\text {nd }}$ Pasture & $76-100$ & -0.28 & -0.27 & -1.79 \\
& Abandonment & $101-150$ & 50.57 & 9.56 & 6.26 \\
\hline
\end{tabular}




\section{Figures}

Figure 1. Schematic representation of key ecosystem processes and interactions (black dotted lines), and mass flows between ecosystem pools (black solid lines). Light and nutrient limitations are simulated explicitly, whereas soil moisture limitation is simulated implicitly (Blanco 2012).

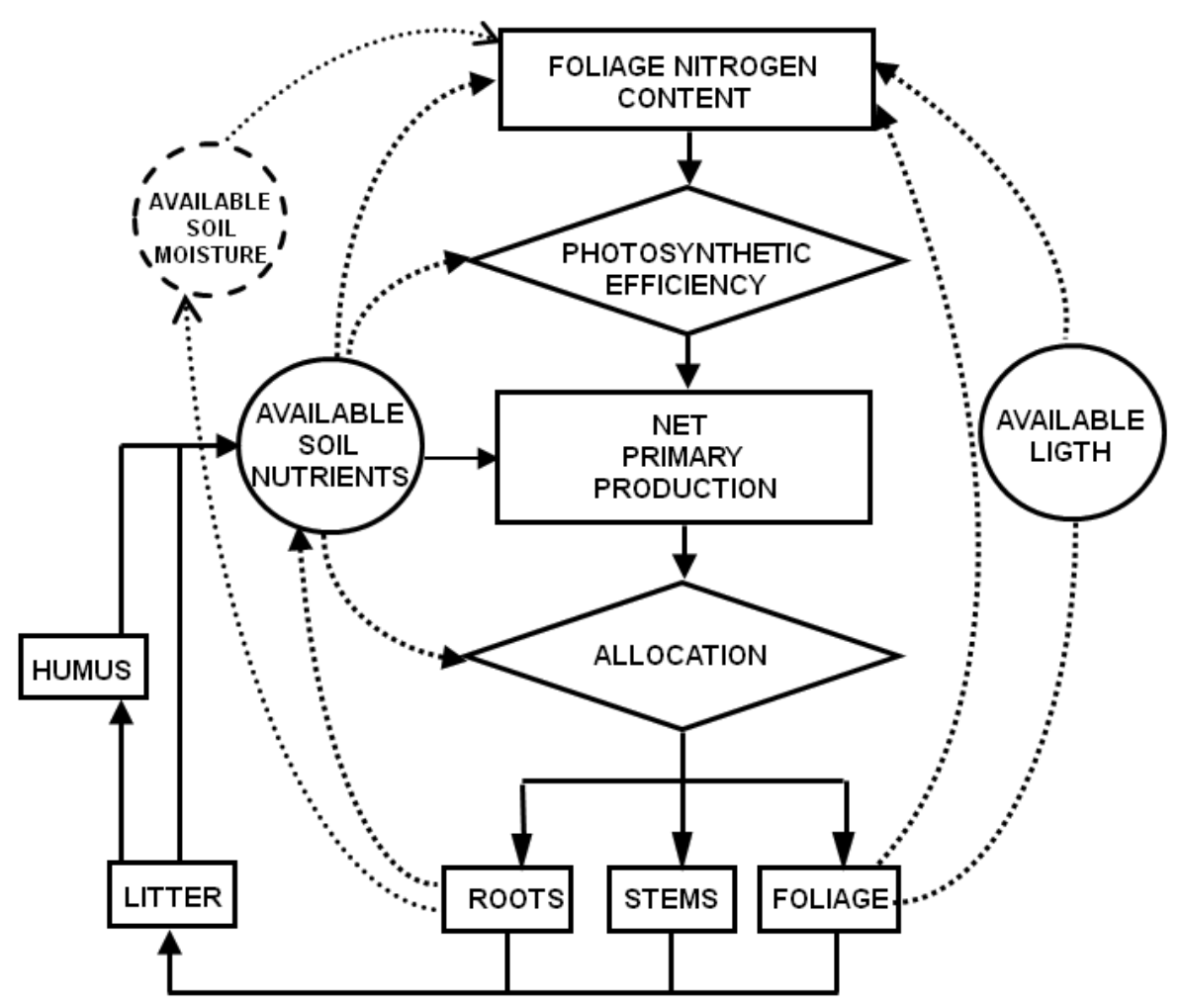

Figure 2. Sequence of calculations carried out by the FORECAST model to estimate $\mathrm{N}$ availability in soils. Step 1: geochemical inputs are calculated, with all the forms of $\mathrm{N}$ lumped together. Step 2: biochemical fluxes (inputs and outputs). Step 3: Plants uptake the available N. Step 4: If soil N exceeds soil CEC (for ammonium) or AEC (for nitrate), exceed $\mathrm{N}$ is subtracted and assumed to be leaching and denitrification losses. Any $\mathrm{N}$ remaining after Step 4 is then carried out to the next year, and becomes the initial $\mathrm{N}$ for the calculations corresponding to the next year (for a complete description of the simulation of these processes see Kimmins et al. 1999).

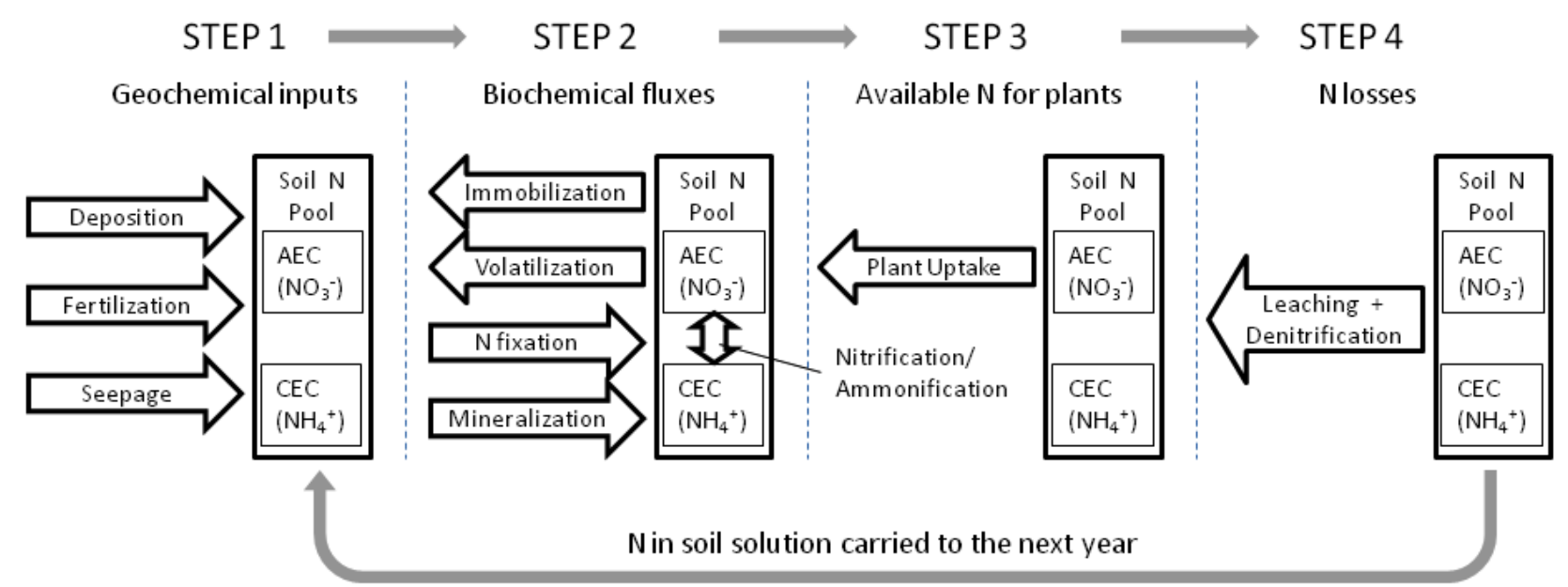


Figure 3. (a) Total ecosystem C (vegetation and soil) in two different sites for two different scenarios (baseline or no management and historical). (b) Soil C (humus, litter and coarse woody debris). (c) Vegetation C. Dots represent field data (mean \pm SD) from the experimental sites of Garde (high elevation) and Aspurz (low elevation) (based on data from Fernández 2013 and Martínez 2015).

\section{HIGH ELEVATION SITE}

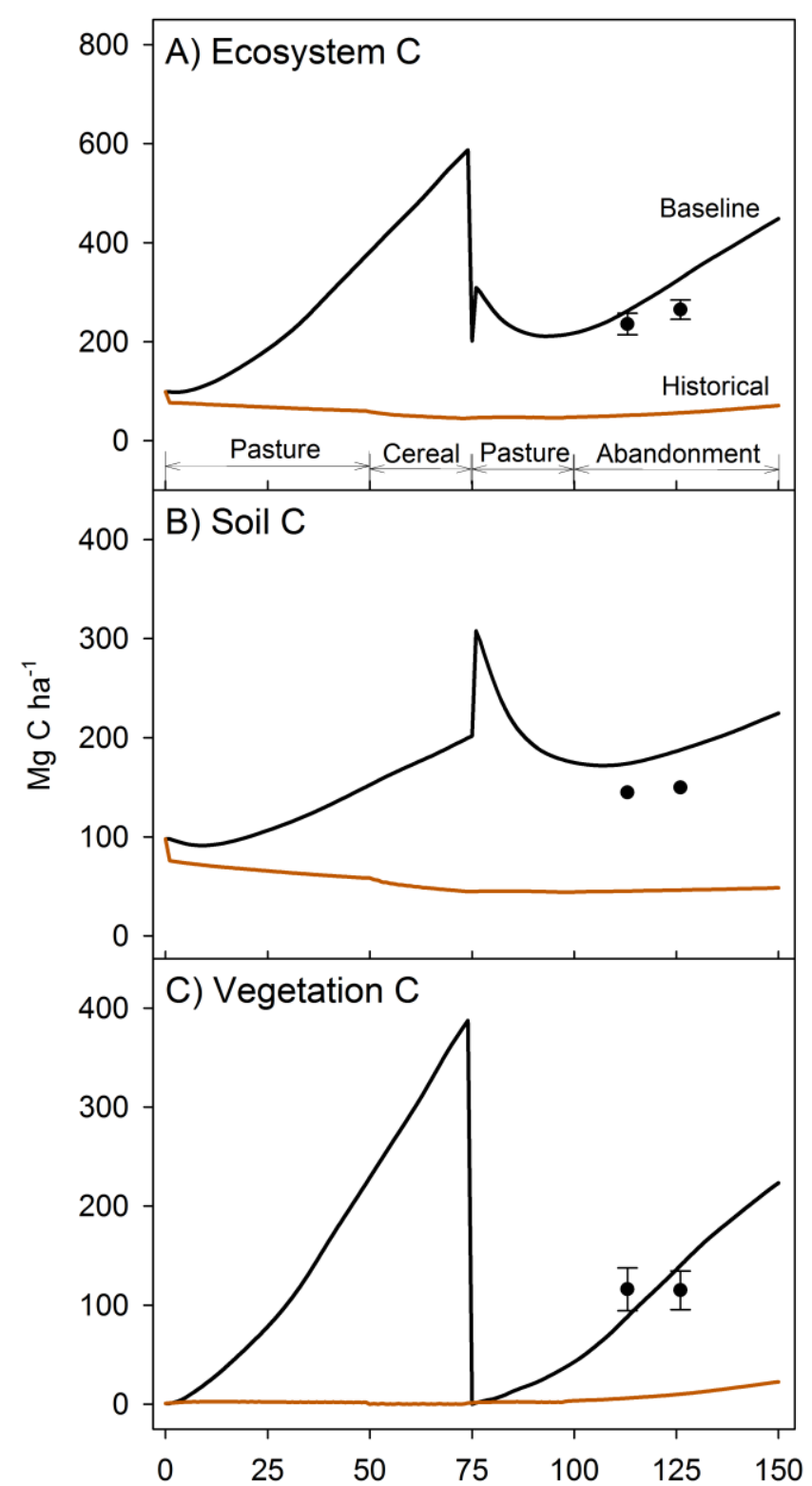

\section{LOW ELEVATION SITE}

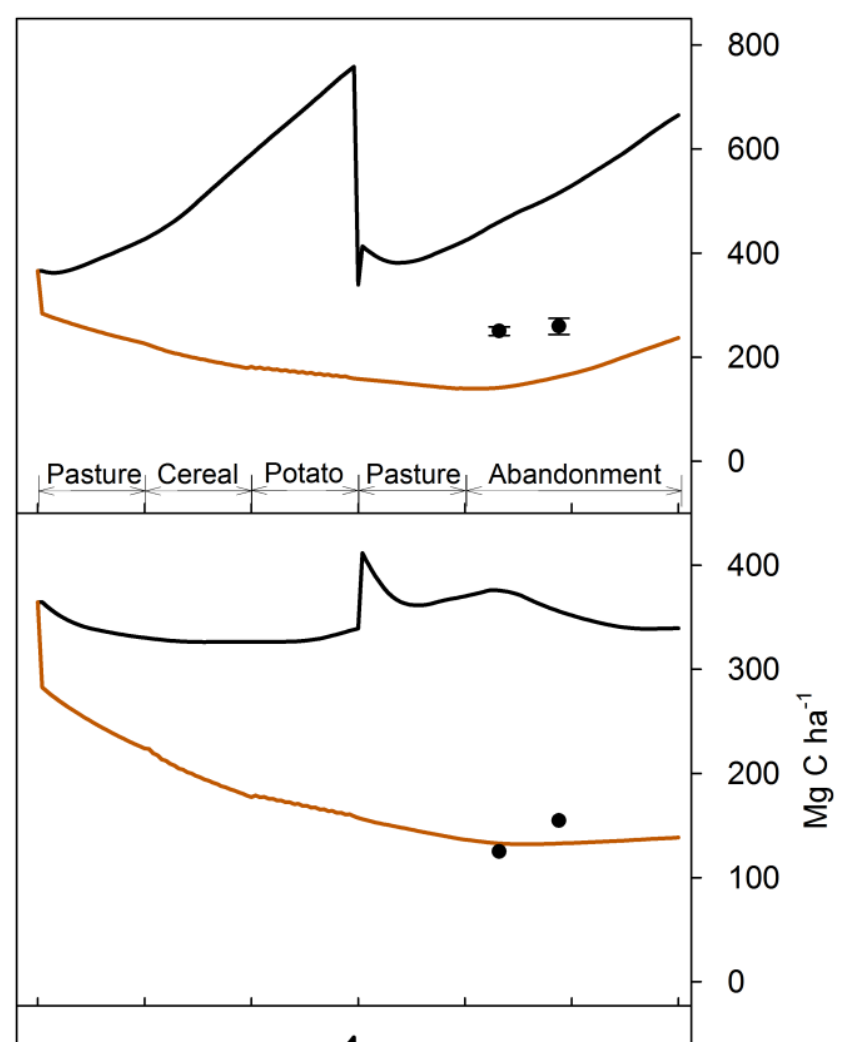

400

Time (years) 
Figure 4. (a) Total soil N (humus, litter and coarse woody debris) in two different sites for two different scenarios (baseline or no management and historical). (b) Five-year running average of available soil $\mathrm{N}$ (see text for a definition).

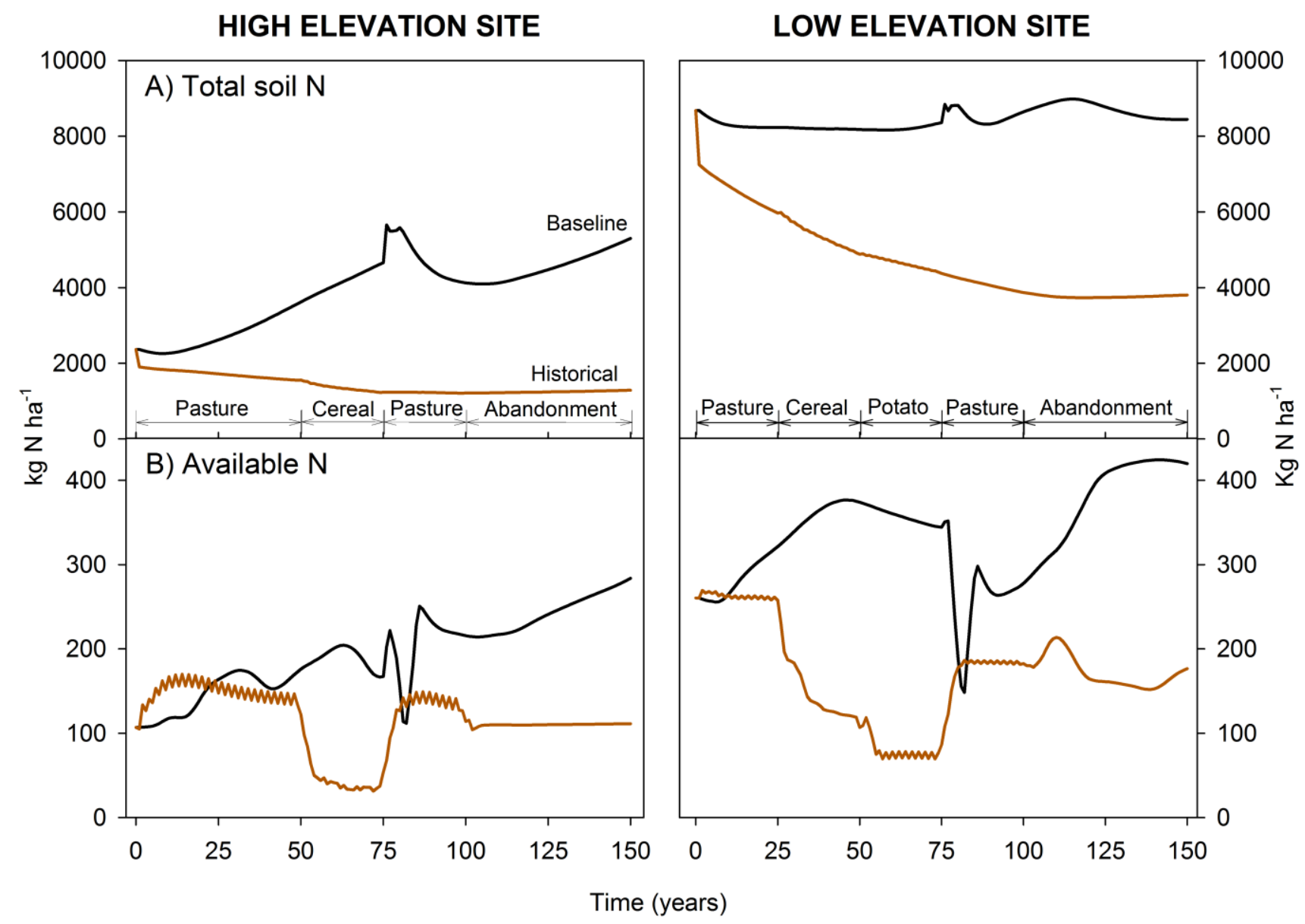

This work is licensed under the Creative Commons Attribution-NonCommercial-NoDerivatives 4.0 International License. To view a copy of this license, visit http://creativecommons.org/licenses/by-nc-nd/4.0/ or send a letter to Creative Commons, PO Box 1866, Mountain View, CA 94042, USA. 